\title{
Cretaceous oceanic anoxic events prolonged by phosphorus cycle feedbacks
}

\author{
Sebastian Beil ${ }^{1}$, Wolfgang Kuhnt ${ }^{1}$, Ann Holbourn ${ }^{1}$, Florian Scholz ${ }^{2}$, Julian Oxmann ${ }^{2}$, Klaus Wallmann ${ }^{2}$, \\ Janne Lorenzen ${ }^{1}$, Mohamed Aquit $^{3}$, and El Hassane Chellai ${ }^{4}$ \\ ${ }^{1}$ Institute of Geosciences, Kiel University, Ludewig-Meyn-Str. 10-14, 24118 Kiel, Germany \\ ${ }^{2}$ GEOMAR Helmholtz Centre for Ocean Research Kiel, Wischhofstr. 1-3, 24148 Kiel, Germany \\ ${ }^{3}$ OCP S.A., Direction de Recherche et Développement, Recherche Géologique, 46300 Youssoufia, Morocco \\ ${ }^{4}$ Department of Geology, Faculty of Sciences Semlalia, Cadi Ayyad University, Marrakesh, Morocco
}

Correspondence: Sebastian Beil (sebastian.beil@ifg.uni-kiel.de) and Wolfgang Kuhnt (wolfgang.kuhnt@ifg.uni-kiel.de)

Received: 13 September 2019 - Discussion started: 8 October 2019

Revised: 27 January 2020 - Accepted: 14 February 2020 - Published: 29 April 2020

\begin{abstract}
Oceanic anoxic events (OAEs) document major perturbations of the global carbon cycle with repercussions for the Earth's climate and ocean circulation that are relevant to understanding future climate trends. Here, we compare the onset and development of Cretaceous OAE1a and OAE2 in two drill cores with unusually high sedimentation rates from the Vocontian Basin (southern France) and Tarfaya Basin (southern Morocco). OAE1a and OAE2 exhibit remarkable similarities in the evolution of their carbon isotope $\left(\delta^{13} \mathrm{C}\right)$ records, with long-lasting negative excursions preceding the onset of the main positive excursions, supporting the view that both OAEs were triggered by massive emissions of volcanic $\mathrm{CO}_{2}$ into the atmosphere. However, there are substantial differences, notably in the durations of individual phases within the $\delta^{13} \mathrm{C}$ positive excursions of both OAEs. Based on analysis of cyclic sediment variations, we estimate the duration of individual phases within OAE1a and OAE2. We identify (1) a precursor phase (negative excursion) lasting $\sim 430 \mathrm{kyr}$ for OAE1a and $\sim 130 \mathrm{kyr}$ for OAE2, (2) an onset phase of $\sim 390$ and $\sim 70 \mathrm{kyr}$, (3) a peak phase of $\sim 600$ and $\sim 90 \mathrm{kyr},(4)$ a plateau phase of $\sim 1340$ and $\sim 200 \mathrm{kyr}$, and (5) a recovery phase of $\sim 380$ and $\sim 440 \mathrm{kyr}$. The total duration of the positive $\delta^{13} \mathrm{C}$ excursion is estimated at $2700 \mathrm{kyr}$ for OAE1a and $790 \mathrm{kyr}$ for OAE2, and that of the main carbon accumulation phase is estimated at 980 and $180 \mathrm{kyr}$. The long-lasting peak, plateau and recovery phases imply fundamental changes in global nutrient cycles either (1) by submarine basalt-seawater interactions, (2) through excess nutrient inputs to the oceans by increasing continen-
\end{abstract}

tal weathering and river discharge, or (3) through nutrient recycling from the marine sediment reservoir. We investigated the role of phosphorus in the development of carbon accumulation by analysing phosphorus speciation across OAE2 and the mid-Cenomanian Event (MCE) in the Tarfaya Basin. The ratios of organic carbon and total nitrogen to reactive phosphorus $\left(\mathrm{C}_{\text {org }} / \mathrm{P}_{\text {react }}\right.$ and $\left.\mathrm{N}_{\text {total }} / \mathrm{P}_{\text {react }}\right)$ prior to OAE2 and the MCE hover close to or below the Redfield ratio characteristic of marine organic matter. Decreases in reactive phosphorus resulting in $\mathrm{C}_{\text {org }} / \mathrm{P}_{\text {react }}$ and $\mathrm{N}_{\text {total }} / \mathrm{P}_{\text {react }}$ above the Redfield ratio during the later phase of OAE2 and the MCE indicate leakage from the sedimentary column into the water column under the influence of intensified and expanded oxygen minimum zones. These results suggest that a positive feedback loop, rooted in the benthic phosphorus cycle, contributed to increased marine productivity and carbon burial over an extended period of time during OAEs.

\section{Introduction}

The Cretaceous period was characterized by high atmospheric $\mathrm{CO}_{2}$ levels and temperatures and by the episodic deposition of sediments with extremely high organic carbon content, referred to as oceanic anoxic events (OAEs; e.g. Schlanger and Jenkyns, 1976; Jenkyns, 1980). These events represent prolonged and intense perturbations of the global carbon cycle (e.g. Arthur et al., 1985) associated with widespread anoxia in most ocean basins. Oceanic anoxic 
events are also characterized by positive carbon isotope $\left(\delta^{13} \mathrm{C}\right)$ excursions that have been related to globally enhanced rates of organic carbon burial (e.g. Berger and Vincent, 1986; Kump, 1991). The most prominent of these events were OAE1a during the early Aptian and OAE2 at the Cenomanian-Turonian boundary. Smaller-scale events of probably more regional extent were also identified in several ocean basins (e.g. OAE1b, c, d, and OAE3). Another such event, the mid-Cenomanian Event (MCE; Coccioni and Galeotti, 2003), appears to represent a less intense precursor event of OAE2. However, detailed records of the MCE are still sparse, with most studies focusing on the higheramplitude events (OAE1a, b, c, d and OAE2). Records of the MCE until now are predominantly from the North Atlantic and Tethys region (e.g. Umbria-Marche Basin, Coccioni and Galeotti, 2003; English chalk, Gale, 1989, Jenkyns et al., 1994; Western Interior Seaway, Keller et al., 2004; Blake Nose, Ando et al., 2009), displaying a positive isotope excursion during the Thalmanninella reicheli foraminiferal zone. In shelf areas of the global ocean, major sea level changes associated with the cycles Ce2.1 and Ce3 of Gale et al. (2002) may have caused long-lasting hiatuses, obliterating evidence of the MCE.

The triggering mechanisms and internal processes that were essential for sustaining high primary productivity over extended periods of time during OAEs remain enigmatic. One of the limitations for understanding the driving mechanisms and dynamics of OAEs is the uncertainty about the duration of OAEs and individual phases within these events. Previous estimates vary substantially (Table 1), partly due to differing definitions of the onset and end of OAEs based on the extent of organic-rich sediment accumulation or the $\delta^{13} \mathrm{C}$ excursion. For instance, the positive shift in the initial part of the excursion is considered to represent the entire OAE1a (e.g. Li et al., 2008; Moullade et al., 2015), whereas the return to background values (e.g. Sageman et al., 2006) or the end of the $\delta^{13} \mathrm{C}$ plateau (e.g. Eldrett et al., 2015) is included in the definition of OAE2.

Carbon isotope excursions associated with OAEs often display an initial negative excursion, which has been attributed to the rapid release of a large volume of ${ }^{13} \mathrm{C}$-depleted carbon as methane and $\mathrm{CO}_{2}$ from organic material in terrigenous soils and sediments, the dissociation of submarine methane hydrates, or the direct volcanic exhalation of $\mathrm{CO}_{2}$ and thermal combustion of organic-rich sediments driven by volcanic heat flux (e.g. Dickens et al., 1995; Jenkyns, 2003; Erba, 2004; Turgeon and Creaser, 2008; Du Vivier et al., 2014). The ensuing positive $\delta^{13} \mathrm{C}$ excursion is generally attributed to enhanced burial rates of ${ }^{12} \mathrm{C}$-enriched organic carbon in marine organic-rich shales and/or in terrestrial peat and coal deposits (e.g. Scholle and Arthur, 1980; Jenkyns, 1980; Schlanger et al., 1987; Arthur et al., 1988). Key constraints on the subsequent feedback mechanisms of nutrient and carbon cycles are the rates at which the carbon was released and buried. Fast release rates are consis- tent with catastrophic events, such as methane hydrate dissociation or the thermal combustion of organic-rich sediments, whereas slower rates implicate other processes. Burial rates influenced the balance between the continuing release of ${ }^{13} \mathrm{C}$-depleted carbon and the relative impact of sequestration through enhanced biological productivity and globally intensified and expanded ocean anoxia.

Different hypotheses have been put forward to explain the enhanced accumulation of organic matter (e.g. Arthur et al., 1988; Jenkyns, 2010) and the processes triggering and maintaining global anoxia and enhanced primary productivity during Cretaceous OAEs. These include fertilization by nutrient input into the ocean system in association with the activity of large igneous provinces (LIPs) (e.g. Schlanger et al., 1981; Larson, 1991; Trabucho-Alexandre et al., 2010), the sea-level-controlled remobilization of nutrients from flooded low-altitude land areas associated with major marine transgressions (e.g. Jenkyns, 1980; Mort et al., 2008), increased phosphorus input resulting from intensified weathering on land (e.g. Larson and Erba, 1999; Poulton et al., 2015), or the release of phosphorus as a main limiting nutrient from sediments into the water column under anoxic bottom water conditions (e.g. Ingall and Jahnke, 1994; Slomp and Van Cappellen, 2007). However, the extent to which and the conditions under which phosphorus was available to act as a fertilizer for marine productivity as well as the mechanisms and internal feedbacks that sustained OAEs for several hundred thousand years remain controversial.

Primary production in the modern marine environment is mainly limited by the availability of nitrogen, iron and phosphorus, with the latter considered the ultimate limiting nutrient on longer geological timescales (Holland, 1978; Broecker and Peng, 1982; Smith, 1984; Codispoti, 1989; Tyrell, 1999; Filipelli, 2008). It has been suggested that the phosphorus budget of the modern ocean is imbalanced, since input fluxes from riverine, aeolian and ice-rafted sources do not fully match phosphorus burial in marine sediments and the hydrothermal removal of dissolved phosphate from the deep ocean (e.g. Wallmann, 2010). The main source for phosphorus in the oceans is the terrigenous discharge from rivers in the form of dissolved inorganic phosphorus (DIP) and organic phosphorus (DOP), particulate inorganic phosphorus (PIP), and particulate organic phosphorus (POP). The delivery rate of $\mathrm{POP}$ and immediately bioavailable reactive DIP and DOP is mainly controlled by continental weathering and seasonal riverine discharge (Ruttenberg, 2003; Li et al., 2017a); it is thus closely linked to variations in atmospheric carbon dioxide concentrations and the hydrological cycle. Most sedimentary rocks and sea-floor sediments are characterized by low concentrations of phosphorus $<0.13 \%$ (Riggs, 1979), and shallow marine environments are considered to be the main phosphorus sinks (Ruttenberg, 1993). Exposure to well-oxygenated water masses on the shelf and slope leads to the almost complete remineralization of or- 
Table 1. Durations of Cretaceous OAEs.

\begin{tabular}{|c|c|c|c|c|}
\hline $\begin{array}{l}\text { Carbon } \\
\text { isotope } \\
\text { excursion }\end{array}$ & Time interval & Duration & Estimate for & Publication \\
\hline \multirow[t]{4}{*}{ OAE1a } & \multirow[t]{4}{*}{$\begin{array}{l}\text { early Aptian to } \\
\text { late Aptian }\end{array}$} & $\sim 1.0-1.3 \mathrm{Myr}$ & $\begin{array}{l}\text { carbon isotope stages } \mathrm{C} 3 \text { to } \mathrm{C} 6 \text { of } \\
\text { Menegatti et al. (1998) in } \delta^{13} \mathrm{C}\end{array}$ & Li et al. (2008) \\
\hline & & $1.11 \pm 0.11 \mathrm{Myr}$ & Selli Level & Malinverno et al. (2010) \\
\hline & & $1.36 \mathrm{Myr}$ & increase to inflection point of $\delta^{13} \mathrm{C}$ & Scott (2014) \\
\hline & & $1.16 \mathrm{Myr}$ & $\begin{array}{l}\text { carbon isotope stages C3 to C6 } \\
\text { of Menegatti et al. (1998) }\end{array}$ & Moullade et al. (2015) \\
\hline \multirow[t]{5}{*}{ OAE1b } & \multirow{5}{*}{$\begin{array}{l}\text { late Aptian to } \\
\text { early Albian }\end{array}$} & $210 \mathrm{kyr}$ & positive isotope excursion in $\delta^{13} \mathrm{C}$ & \multirow[t]{2}{*}{ Erbacher et al. (2001) } \\
\hline & & $46 \mathrm{kyr}$ & black shale deposition & \\
\hline & & $45 \mathrm{kyr}$ & $\begin{array}{l}\text { negative excursion and increase to } \delta^{13} \mathrm{C} \\
\text { maximum }\end{array}$ & \multirow[t]{2}{*}{ Wagner et al. (2007) } \\
\hline & & $40 \mathrm{kyr}$ & positive isotope excursion in $\delta^{13} \mathrm{C}$ & \\
\hline & & $1.84 \mathrm{Myr}$ & & Scott $(2014)$ \\
\hline OAE1c & middle Albian & $1.01 \mathrm{Myr}$ & increase to $\delta^{13} \mathrm{C}$ maximum & Scott (2014) \\
\hline \multirow[t]{5}{*}{ OAE1d } & \multirow{5}{*}{$\begin{array}{l}\text { Albian - } \\
\text { Cenomanian } \\
\text { boundary } \\
\text { interval }\end{array}$} & $\sim 400 \mathrm{kyr}$ & increase to $\delta^{13} \mathrm{C}$ maximum & Petrizzo et al. (2008) \\
\hline & & $\sim 1 \mathrm{Myr}$ & $\begin{array}{l}\text { ACBI (Albian-Cenomanian boundary } \\
\text { interval) from the onset of peak A } \\
\text { (OAE1d) to the return to background } \\
\text { values after peak D in } \delta^{13} \mathrm{C}\end{array}$ & Bornemann et al. (2017) \\
\hline & & $1.21 \pm 0.17 \mathrm{Myr}$ & $\begin{array}{l}\text { OAE1d from the onset of peak A } \\
\text { to peak } \mathrm{C} \text { in } \delta^{13} \mathrm{C}\end{array}$ & Gambacorta et al. (2019) \\
\hline & & $233 \mathrm{kyr}$ & onset and peak phase in $\delta^{13} \mathrm{C}$ & Yao et al. (2018) \\
\hline & & $\sim 400 \mathrm{kyr}$ & increase to inflection point in $\delta^{13} \mathrm{C}$ & Scott (2014) \\
\hline \multirow[t]{3}{*}{ MCE } & middle & $\sim 200 \mathrm{kyr}$ & onset to second peak in $\delta^{13} \mathrm{C}$ & Voigt et al. (2004) \\
\hline & \multirow[t]{2}{*}{ Cenomanian } & $<400 \mathrm{kyr}$ & onset to second peak in $\delta^{13} \mathrm{C}$ & Reboulet et al. (2013) \\
\hline & & $210 \mathrm{kyr}$ & onset until return to background values in $\delta^{13} \mathrm{C}$ & Eldrett et al. (2015) \\
\hline \multirow[t]{7}{*}{ OAE2 } & \multirow{7}{*}{$\begin{array}{l}\text { Cenomanian - } \\
\text { Turonian } \\
\text { boundary } \\
\text { interval }\end{array}$} & $563-601 \mathrm{kyr}$ & onset, peak and plateau phase in $\delta^{13} \mathrm{C}$ & \multirow[t]{2}{*}{ Sageman et al. (2006) } \\
\hline & & $847-885 \mathrm{kyr}$ & onset, peak, plateau and recovery phase in $\delta^{13} \mathrm{C}$ & \\
\hline & & $450-500 \mathrm{kyr}$ & $\begin{array}{l}\text { in S13 (Tarfaya Basin) between onset and end } \\
\text { of plateau in } \delta^{13} \mathrm{C}\end{array}$ & \multirow[t]{2}{*}{ Meyers et al. (2012a) } \\
\hline & & $500-550 \mathrm{kyr}$ & $\begin{array}{l}\text { in } 1261 \mathrm{~B} \text { (Demerara Rise) between onset and end } \\
\text { of plateau in } \delta^{13} \mathrm{C}\end{array}$ & \\
\hline & & $516-613 \mathrm{kyr}$ & $\begin{array}{l}\text { in Angus Core (Western Interior } \\
\text { Seaway); onset, peak, plateau and } \\
\text { recovery phase in } \delta^{13} \mathrm{C}\end{array}$ & \multirow[t]{2}{*}{ Ma et al. (2014) } \\
\hline & & $559-675 \mathrm{kyr}$ & $\begin{array}{l}\text { in Portland Core (Western Interior } \\
\text { Seaway); onset, peak, plateau and } \\
\text { recovery phase in } \delta^{13} \mathrm{C}\end{array}$ & \\
\hline & & $520 \mathrm{kyr}$ & onset phase in $\delta^{13} \mathrm{C}$ & Scott (2014) \\
\hline
\end{tabular}


Table 1. Continued.

\begin{tabular}{|c|c|c|c|c|}
\hline \multirow[t]{9}{*}{$\begin{array}{l}\text { Carbon } \\
\text { isotope } \\
\text { excursion }\end{array}$} & Time interval & Duration & Estimate for & Publication \\
\hline & & $710 \pm 170 \mathrm{kyr}$ & onset until end of plateau phase in $\delta^{13} \mathrm{C}$ & Eldrett et al. (2015) \\
\hline & & $920 \pm 170 \mathrm{kyr}$ & $\begin{array}{l}\text { negative excursion, onset, peak and } \\
\text { plateau phase in } \delta^{13} \mathrm{C}\end{array}$ & \\
\hline & & $\sim 900 \mathrm{kyr}$ & onset until end of plateau phase in $\delta^{13} \mathrm{C}$ & Jenkyns et al. (2017) \\
\hline & & $650 \pm 25 \mathrm{kyr}$ & onset until end of plateau phase in $\delta^{13} \mathrm{C}$ & Li et al. (2017b) \\
\hline & & $820 \mathrm{kyr}$ & $\begin{array}{l}\text { onset, peak, plateau and } \\
\text { recovery phase in } \delta^{13} \mathrm{C}\end{array}$ & \\
\hline & & $675 \mathrm{kyr}$ & onset until end of plateau phase in $\delta^{13} \mathrm{C}$ & Charbonnier et al. (2018) \\
\hline & & $956 \mathrm{kyr}$ & $\begin{array}{l}\text { onset, peak, plateau and } \\
\text { recovery phase in } \delta^{13} \mathrm{C}\end{array}$ & \\
\hline & & $930 \pm 25 \mathrm{kyr}$ & onset until end of plateau phase in $\delta^{13} \mathrm{C}$ & Gangl et al. (2019) \\
\hline
\end{tabular}

ganic matter and precipitation of authigenic phosphorus minerals (Ruttenberg and Berner, 1993).

In deep-sea sediments underlying well-oxygenated bottom water masses, phosphorus remains mainly bound to manganese oxides and iron oxides as well as iron hydroxides and as authigenic calcium-bound phosphorus (Supplement Sect. S1), which typically exhibits C : P below the Redfield ratio. Excess phosphate is released from shelf and continental margin sediments deposited in low oxygen environments, resulting in elevated sedimentary $\mathrm{C}: \mathrm{P}$. Today, estimates of residence time vary between 10-17 kyr (Ruttenberg, 2003) and $80 \mathrm{kyr}$ (Broecker and Peng, 1982), depending on estimated burial rates within the different marine phosphorus sinks, in particular in shallow seas and along continental margins (Ruttenberg, 2003). During Cretaceous OAEs, the extent and burial efficiency of these sinks must have varied substantially due to sea level and redox oscillations affecting marginal seas (e.g. Danzelle et al., 2018).

There are conflicting views on the influence of expanded oxygen minimum zones (OMZs) or oceanic anoxia on the phosphorus cycle and, in particular whether OMZ sediments serve as a phosphorus source or sink. It has been argued that oxygen-depleted bottom waters favour phosphorus release from the sediment to the water column (Ingall and Jahnke, 1994) and stimulate primary production in surface waters (Wallmann, 2003). This in turn results in increased organic carbon export flux, leading to higher oxygen demand, OMZ expansion and intensification, and a positive feedback with benthic phosphorus release (Slomp and Van Cappellen, 2007; Wallmann, 2010). By contrast, other studies suggested that intensified phosphorus burial occurs under anoxic conditions in shallow water environments based on observations of calcium fluorapatite (CFA) precipitation in present-day shallow water oxygen-depleted upwelling areas (Schulz and Schulz, 2005; Arning et al., 2009a, b; Goldhammer et al., 2010; Ingall, 2010; Cosmidis et al., 2013). In the long term, the formation of CFA is approximately in balance with enhanced phosphorus release from anoxic sediments, implying that the dissolved oceanic phosphorus inventory is largely unaffected by regional changes in oxygen concentrations (Delaney, 1998; Anderson et al., 2001; Roth et al., 2014). However, this equilibrium may have been disturbed during periods of deepwater anoxia, as in the Mediterranean Sea during sapropel formation (Slomp et al., 2004) and in the Cretaceous ocean during OAEs (e.g. Mort et al., 2007, 2008). Observations and model simulations have indicated that global warming enhances the terrestrial input of biologically reactive phosphorus to the marine environment, leading to the increased production and burial of organic carbon in marine sediments (Mackenzie et al., 2002).

In this study, we focus on the two most intense OAEs, OAE1a and OAE2, which occurred during intervals of extreme greenhouse gas forcing within the Cretaceous period. We analyse extended, continuous sediment successions from two drill cores in the Vocontian Basin (southern France) and Tarfaya Basin (southern Morocco) (Fig. 1). Time series analyses of high-resolution X-Ray fluorescence (XRF) scanning elemental and natural gamma ray (NGR) borehole logging data provide constraints on the duration of individual phases within these carbon isotope excursions and new insights into the response of the ocean-climate system to these extreme carbon cycle perturbations. In addition, we analyse phosphorus speciation across the mid-Cenomanian carbon isotope event (MCE) and OAE2 to investigate relationships with changing sea level, OMZ intensity and carbon burial as well as to test the hypothesis of redox-controlled phosphorus re- 


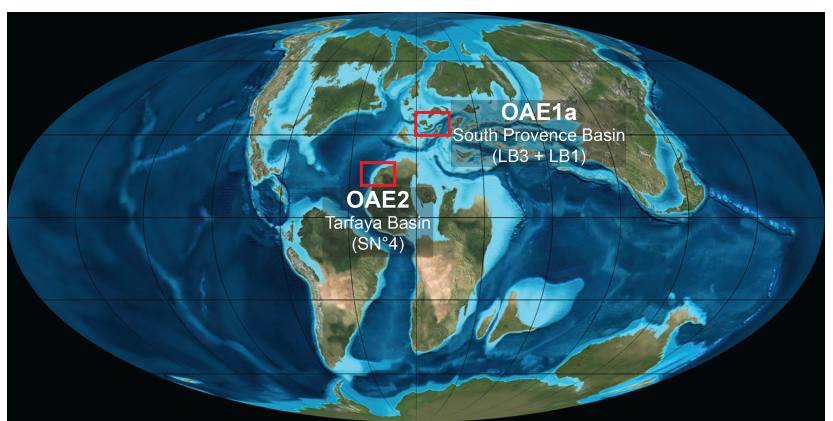

Figure 1. Reconstruction of Late Cretaceous paleogeography at $100 \mathrm{Ma}$ (Ron Blakey, Colorado Plateau Geosystems). Red boxes indicate the locations of the South Provence and Tarfaya basins.

lease as a nutrient source initiating and/or enhancing carbon burial during OAEs.

\section{Material and methods}

\subsection{Sediment cores}

Core $\mathrm{SN}^{\circ} 4\left(27^{\circ} 59^{\prime} 46.4^{\prime \prime} \mathrm{N}, 12^{\circ} 32^{\prime} 40.6^{\prime \prime} \mathrm{W}\right)$ was retrieved in the Tarfaya Basin (southern Morocco), $40 \mathrm{~km}$ east of the town of Tarfaya, close to the road to Tan-Tan. The $350 \mathrm{~m}$ long marine sediment succession in Core $\mathrm{SN}^{\circ} 4$, which provides an expanded record of OAE2, was deposited in an outer shelf setting within a subsiding basin on a passive margin during the Late Cretaceous. Late Albian to Turonian stable isotope and geochemical records were previously presented by Beil et al. (2018) and Scholz et al. (2019). Highresolution XRF scanner, bulk sediment stable isotope and carbon records across the onset of OAE2 were provided by Kuhnt et al. (2017). Here, we complement these records with phosphorus speciation data and time series analysis of logging natural gamma ray and high-resolution XRF scanner elemental distribution data across OAE2.

Cores LB1 $\left(43^{\circ} 14^{\prime} 37^{\prime \prime} \mathrm{N}, 5^{\circ} 34^{\prime} 12^{\prime \prime} \mathrm{E} ; 70 \mathrm{~m}\right.$ long) and LB3 $\left(43^{\circ} 14^{\prime} 42^{\prime \prime} \mathrm{N}, 5^{\circ} 34^{\prime} 52^{\prime \prime} \mathrm{E}\right.$; $56 \mathrm{~m}$ long) were drilled near Roquefort-La-Bédoule, $16 \mathrm{~km}$ southeast of Marseille in southern France. During the Aptian, the coring sites were located within an isolated intra-shelf basin, the South Provence Basin, on the northern Provençal carbonate platform, where an expanded succession of marine sediments including OAE1a accumulated. Details of the drilling operation were published by Flögel et al. (2010), lithologic descriptions, biostratigraphy and intermediate-resolution carbonate and stable isotope measurements were provided by Lorenzen et al. (2013) and Moullade et al. (2015). Here, we present new high-resolution bulk carbonate isotope data across the precursor, onset and peak phases of OAE1a as well as time series analysis of logging natural gamma ray and XRF scanner elemental distribution data from a spliced composite record of LB1 and LB3. The tie point between the two cores is at a depth of $49.4 \mathrm{~m}$ (Section $34,3 \mathrm{~cm} \mathrm{sec}$ tion depth) in LB3 and $10.83 \mathrm{~m}$ (Section $8,95 \mathrm{~cm}$ section depth) in LB1, below bed 170, identified by Moullade et al. (2015) as a prominent correlating feature. The tie point was selected at the base of a prominent, extended maximum in XRF-scanner-derived $\log (\mathrm{Terr} / \mathrm{Ca})$ (Sect. 2.3) identified in both cores.

\subsection{NGR logging}

Wireline borehole logging of the $\mathrm{SN}^{\circ} 4$ drill hole was carried out by Geoatlas (Laayoune, Morocco) using a Century geophysical logging system with a natural gamma ray (NGR) sensor. Detailed information on NGR logging of $\mathrm{SN}^{\circ} 4$ is given in Beil et al. (2018). For borehole logging of the LB1 and LB3 drill holes, an Antares Aladdin logging system with GR5 sensor probe was deployed. All logging operations were conducted shortly after completion of the drilling operation in boreholes without metal casing, and NGR data are presented as American Petroleum Institute radioactivity units in counts per second (cps) with vertical resolutions of $0.1 \mathrm{~m}$ for $\mathrm{SN}^{\circ} 4,0.05 \mathrm{~m}$ for $\mathrm{LB} 1$ and $0.025 \mathrm{~m}$ for LB3. The intensity of natural gamma radiation is predominantly influenced by the concentration of three different elements: potassium $(\mathrm{K})$, uranium $(\mathrm{U})$ and thorium $(\mathrm{Th})$. All three elements are bound to clay minerals, with uranium also adhesively enriched in organic matter. In environments with low terrigenous input and high organic matter accumulation as in Core $\mathrm{SN}^{\circ} 4$, NGR is predominantly controlled by the concentration of organic matter. By contrast, clay accumulation mainly controlled NGR in Cores LB3 and LB1, where the organic matter content of the sediment is low.

\subsection{XRF scanning and line scan imaging}

Detailed descriptions of the XRF scanning of Core $\mathrm{SN}^{\circ} 4$ are provided in Kuhnt et al. (2017) and Beil et al. (2018). Sections were scanned with a second-generation Avaatech X-ray fluorescence scanner at Kiel University. Surfaces were covered with a $4 \mu \mathrm{m}$ thick Ultralene foil after cleaning with finegrained sandpaper. Data for this study are from the $10 \mathrm{kV}$ dataset scanned with a spatial resolution of $1 \mathrm{~cm}$ (vertical slit of $1 \mathrm{~cm}$, horizontal slit of $1.2 \mathrm{~cm}$ ) measured with $10 \mathrm{kV}$, $750 \mu \mathrm{A}$, no filter and $10 \mathrm{~s}$ acquisition time. Sections of Cores LB 1 and LB3 were polished with fine-grained sandpaper and covered with $4 \mu \mathrm{m}$ thick Ultralene foil prior to scanning with the Avaatech XRF scanner at Kiel University. The XRF data from the $10 \mathrm{kV}$ dataset presented in this study were measured with a spatial resolution of $1 \mathrm{~cm}$ with the tube setting of $10 \mathrm{kV}, 250 \mu \mathrm{A}$ and no filter with $15 \mathrm{~s}$ acquisition time.

Raw XRF spectra from all three cores were converted with the iterative least-square package Win Axil batch (Canberra Eurisys) and the $10 \mathrm{kV}$ Kiel model into element-specific area counts. The Jai CV-L 1073 CCD colour line scan camera installed in the Avaatech XRF scanner at Kiel University 
was used to obtain core images with a downcore resolution of 143 ppcm for Cores $\mathrm{SN}^{\circ} 4, \mathrm{LB} 1$ and LB3. We used the logarithmic ratios of elemental counts to eliminate XRFscanning-specific effects such as the matrix effect, grain size effect or variations in rock density (Weltje and Tjallingii, 2008).

$\log (\mathrm{Terr} / \mathrm{Ca})$ is used as a proxy for terrigenous, clastic material vs. marine biogenic carbonate. Elements of typically terrigenous origin (Terr) detected with the $10 \mathrm{kV}$ settings are aluminium $(\mathrm{Al})$, iron $(\mathrm{Fe})$, potassium $(\mathrm{K})$, silicon $(\mathrm{Si})$ and titanium (Ti) (e.g. Peterson et al., 2000; Calvert and Pedersen, 2007; Mulitza et al., 2008; Tisserand et al., 2009; Govin et al., 2012). The variability of Fe closely matches the variability of the other terrigenous elements (Sect. S2), thus appearing not to be influenced by changing redox conditions. Calcium (Ca) is of marine origin, mainly from calcareous nanoplankton and microplankton. $\log (\mathrm{K} / \mathrm{Al})$ is widely used to characterize the composition of clay mineral assemblages (Weaver, 1967, 1989; Niebuhr, 2005). The ratio is primarily controlled by variations in the amount of potassium-rich illite and thus reflects the intensity of physical and chemical weathering in the source area (Calvert and Pedersen, 2007).

\subsection{Stable isotopes}

Organic and bulk carbonate stable isotope data from Core $\mathrm{SN}^{\circ} 4$ were compiled from the high-resolution record over the onset of OAE2 (Kuhnt et al., 2017) and from the lowerresolution record over the entire core (Beil et al., 2018). Bulk carbonate samples were analysed with the Finnigan MAT 251 and MAT 253 mass spectrometers at the Leibniz Laboratory for Radiometric Dating and Stable Isotope Research at Kiel University. The accuracy for carbon isotopes was $\pm 0.05 \%$ and $\pm 0.08 \%$ o for oxygen isotopes. Organic carbon stable isotopes were analysed at the GeoZentrum Nordbayern (Erlangen) with a Flash EA 2000 Elemental Analyzer coupled to a Thermo Finnigan Delta V Plus mass spectrometer on samples with a spacing between $\sim 0.1$ and $\sim 2.3 \mathrm{~m}$. Measurement accuracy was $\pm 0.06 \%$. Results are reported on the delta scale as $\delta^{18} \mathrm{O}, \delta^{13} \mathrm{C}_{\text {carbonate }}$ and $\delta^{13} \mathrm{C}_{\text {org }}$ against the Vienna PeeDee Belemnite (VPDB) standard.

Initial stable isotope data from Cores LB1 and LB3 were presented in Lorenzen et al. (2013) and Moullade et al. (2015). Published data have a spacing of $\sim 20 \mathrm{~cm}$ in LB1 and $\sim 40 \mathrm{~cm}$ in LB3. New samples were analysed to increase the resolution to $\sim 5 \mathrm{~cm}$ during the early part of OAE1a between 18 and $41.5 \mathrm{~m}$ in Core LB1. Stable isotopes of bulk carbonate samples were analysed at the Leibniz Laboratory for Radiometric Dating and Stable Isotope Research at Kiel University with a Finnigan MAT 251 mass spectrometer. Analytical uncertainty for stable carbon isotopes was $\pm 0.04 \%$ o and $\pm 0.07 \%$ for stable oxygen isotopes. Results are reported on the delta scale as $\delta^{18} \mathrm{O}$ and $\delta^{13} \mathrm{C}_{\text {carbonate }}$ against the Vienna PeeDee Belemnite (VPDB) standard.

\subsection{Total organic carbon, carbonate and nitrogen content}

Aliquots of samples for the determination of major and trace elements as well as phosphorus speciation in Core $\mathrm{SN}^{\circ} 4$ were analysed for total organic carbon (TOC), carbonate and nitrogen content. Replicates of 8-10 mg sample material were pulverized, homogenized and sealed into tin capsules for the determination of total carbon (TC) and nitrogen (N) and into silver capsules followed by decarbonatization with $0.25 \mathrm{~N}$ hydrochloric acid $(\mathrm{HCl})$ to measure TOC. Different weights of acetanilid $(10.36 \% \mathrm{~N}, 71.09 \% \mathrm{C})$ and of the certified soil standard BSTD1 $(0.216 \% \mathrm{~N}, 3.5 \% \mathrm{C})$ were sealed and measured for calibration and the monitoring of long-term stability. All capsules were measured with a Carlo Erba Protein Analyzer NA1500 at the GEOMAR Helmholtz Centre for Ocean Research Kiel. Carbonate content (TIC) was calculated as TIC $=($ TC-TOC $) \times 8.3333$.

\subsection{Time series analysis}

The package astrochron (Meyers and Sageman, 2007; Meyers et al., 2012a; Meyers, 2014) for R (R Core Team, 2018) was used to perform frequency analysis on the NGR and XRF $\log (\mathrm{Terr} / \mathrm{Ca})$ datasets. The NGR datasets were linearly interpolated to a spatial resolution of $0.1 \mathrm{~m}$ for Core $\mathrm{SN}^{\circ} 4$ and $0.025 \mathrm{~m}$ for the spliced dataset of Cores LB1-LB3. XRFscanner-derived $\log (\mathrm{Terr} / \mathrm{Ca})$ from LB3 and LB1 was linearly interpolated to a spatial resolution of $0.01 \mathrm{~m}$. Longterm variability of $>20 \mathrm{~m}$ wavelengths was removed from the NGR dataset by using a Gaussian kernel smoother with the function noKernel of astrochron.

Dominant frequencies in Cores LB1 and LB3 were extracted with the robust red noise multitaper method (MTM) spectral analysis of Mann and Lees (1996) using the function mtmML96 (Patterson et al., 2014) of astrochron with five $2 \pi$ prolate tapers. Visualization and checks were performed with the eha function of astrochron with three $2 \pi$ prolate tapers and a window of $6 \mathrm{~m}$ over the frequency range between 0 and 4 cycles per metre for the spliced record of LB1 and LB3. Identical intervals and frequency ranges were used to check results with the complementary XRF-scanner-derived $\log$ (Terr/Ca) (Fig. S3.1).

An age model for Core $\mathrm{SN}^{\circ} 4$ was derived by correlating the NGR record with that of the neighbouring Core S13 (Meyers et al., 2012a) following Kuhnt et al. (2017). A total of 14 tie points delimiting characteristic features of both cores were used (Sect. S4). The age model of Meyers et al. (2012a) was transferred into chronological ages by anchoring the Cenomanian-Turonian boundary at the top of cycle 3 to the chronological age of $93.9 \mathrm{Ma}$ (Meyers et al., 2012b).

Periodicities for precession, obliquity and eccentricity are based on the orbital solution La04 (Laskar et al., 2004). Additional periodicities for eccentricity were extracted from the 
orbital solutions La10a-d (Laskar et al., 2011a) for the Cenomanian and Aptian intervals and La10a-d and La11 (Laskar et al. 2011a, b) for the Cenomanian interval using the $a s$ trochron function mtmML96 (Patterson et al., 2014). The analysis of orbital parameters for OAE1a was limited to the Aptian interval between 113 and $126 \mathrm{Ma}$ and to the Cenomanian interval between 93 and 99 Ma for OAE2 (Sect. S5). Ratios were calculated for the main frequencies. Periodicities and ratios of the different orbital cycles are presented in Supplement Fig. S5.1 and Table S5.2 for the Aptian and in Table S5.3 for the Cenomanian interval.

\subsection{Phosphorus speciation and analysis of major and trace elements}

The distribution of major and trace elements as well as phosphorus speciation were determined on new samples from Core $\mathrm{SN}^{\circ} 4$, mainly taken close to the published organic stable isotope samples (Beil et al., 2018). Samples cover the interval between $42.11 \mathrm{~m}$ (Section 18, Segment 3, 23-24 cm) and $305.77 \mathrm{~m}$ (Section 111, Segment 2, 29-31 cm). The core was sampled every $\sim 2.4 \mathrm{~m}$ with an increased resolution of $\sim 1.2 \mathrm{~m}$ over the global isotope excursions within OAE2 and the MCE. The surface of samples was cleaned with a metalfree porcelain knife and ground down with a rotary mill with agate balls to prevent metallic contamination. The powdered material was subdivided into aliquots for major and trace elements analysis and material for the determination of phosphorus speciation. A further aliquot was used for carbonate and organic carbon measurements for samples not close to the already published organic isotope samples. Additional samples from high-carbonate-content intervals were prepared and measured to determine the influence of low clay and organic content.

\subsubsection{Analysis of major and trace elements}

Aliquots of $100 \mathrm{mg}$ were weighed into polytetrafluorethylene (PTFE) vessels. Each sample was treated with $2 \mathrm{~mL} \mathrm{HF}$, $2 \mathrm{~mL} \mathrm{HNO}_{3}$ and $3 \mathrm{~mL} \mathrm{HClO}_{4}$, sealed, and heated for $8 \mathrm{~h}$ at $185^{\circ} \mathrm{C}$. The acid was subsequently smoked off at $190^{\circ} \mathrm{C}$. The almost dry residue was dissolved again in $1 \mathrm{~mL} \mathrm{HNO}_{3}$, smoked off and dissolved again in $5 \mathrm{~mL}$ ultrapure water and $1 \mathrm{~mL} \mathrm{HNO}_{3}$ to be heated again for $2 \mathrm{~h}$ in sealed vessels. The solution was finally transferred and diluted with $10 \mathrm{~mL} \mathrm{HNO}_{3}$ in volumetric flasks. The solutions were measured with a Varian 720-ES ICP-OES for major elements and an Agilent Technologies 7500 Series inductively coupled plasma optical emission spectrometer (ICP-MS) for trace elements at the GEOMAR Helmholtz Centre for Ocean Research Kiel. Accuracy for phosphorus concentrations based on repeated measurements of the standard MESS-3 (National Research Council of Canada) was $2.2 \%(n=15)$. Precision based on duplicate measurements of samples was on average $0.9 \%(n=15)$.

\subsubsection{Phosphorus speciation}

Samples for the measurement of phosphorus speciation were aliquots from samples used for the analysis of major and trace elements. A modified CONVEX extraction method (Oxmann et al., 2008; Sect. S6) was used to extract Cabound as well as $\mathrm{Al} / \mathrm{Fe}$-oxyhydroxide-bound phosphorus. The sample material $(250 \mathrm{mg})$ was subsequently treated with $3.75 \mathrm{~mL} \mathrm{KCl} / \mathrm{EtOH}$ and decanted, and the supernatants were discarded three times. Al/Fe-bound phosphorus was extracted from the centrifuged residue with the addition of $3.75 \mathrm{~mL} \mathrm{NaOH} / \mathrm{Na}_{2} \mathrm{SO}_{4}$ (incubated for $1 \mathrm{~h}$ at $25^{\circ} \mathrm{C}$ ), then $3.75 \mathrm{~mL} \mathrm{NaOH} / \mathrm{Na}_{2} \mathrm{SO}_{4}$ (incubated for $2 \mathrm{~h}$ at $99^{\circ} \mathrm{C}$ ) and finally $7 \mathrm{~mL} \mathrm{Na} \mathrm{SO}_{4}$. Solutions were centrifuged and decanted after each of the three treatment steps and stored for measurement. The centrifuged residue was decarbonated for $8 \mathrm{~h}$ with $3.75 \mathrm{~mL} \mathrm{H}_{2} \mathrm{SO}_{4}$. The Ca-bound phosphorus fraction was extracted by adding a further $3.75 \mathrm{~mL} \mathrm{H}_{2} \mathrm{SO}_{4}$ (incubated for $2 \mathrm{~h}$ at $99^{\circ} \mathrm{C}$ ) and twice $\mathrm{Na}_{2} \mathrm{SO}_{4}(3.75$ and $7 \mathrm{~mL}$ ). Each of the three steps was followed by centrifugation and decanting of the solution. Supernatants of each step were again mixed and stored for measurements. Details are provided in Fig. S6.1.

For the measurement of Ca-bound phosphorus, an aliquot of $0.1 \mathrm{~mL}$ was diluted with $4.9 \mathrm{~mL}$ Milli-Q. Concentrations of $\mathrm{Al} / \mathrm{Fe}$-bound phosphorus were measured on $4.5 \mathrm{~mL}$ of sample solution equilibrated with the addition of $0.5 \mathrm{~mL}$ of sol7 (Table S6.2) to a $\mathrm{pH}$ of $\sim 1$. Concentrations of $\mathrm{Al} / \mathrm{Fe}-$ and Ca-bound phosphorus were calibrated with the $\mathrm{PO}_{4}$ Merck Standard ( $1000 \mathrm{mg} \mathrm{PO}_{4} \mathrm{~L}^{-1}$ ) diluted to specific concentrations. The ammonium molybdate solution $(0.1 \mathrm{~mL}$; Table S6.3) was added $30 \mathrm{~min}$ before measurements. For samples close to the photometric saturation level a new aliquot was diluted to a lower concentration within the measurement range. A detailed list with the chemicals used and their respective concentrations is available in Table S6.2.

The atomic ratio of organic carbon to $\mathrm{P}_{\text {reactive }}$ (defined as the sum of loosely absorbed, organic, authigenic and ironbound phosphorus) was interpreted by Anderson et al. (2001) as a proxy for marine paleoproductivity. Due to sink switching (transfer to different phosphorus pools) between the different phosphorus species, especially during early diagenesis, the authors assumed that phosphorus in the different pools was originally derived from the remineralization of organic material and could therefore be considered equivalent to $\mathrm{P}_{\text {org }}$. Here, $\mathrm{P}_{\text {react }}$ is calculated by summing up the two CONVEX-derived $\mathrm{P}$ pools: $\mathrm{CaP}$ (seen as equivalent to $\left.\mathrm{P}_{\text {auth }}\right)$ and AlFeP. Both loosely absorbed and organic $\mathrm{P}$ were not measured. It is assumed that the concept of Andersen et al. (2001) is applicable, as both extracted $\mathrm{P}$ pools $(\mathrm{CaP}$ and $\mathrm{AlFeP}$ ) contain the majority of $\mathrm{P}_{\text {total }}$ (mean $=89 \%$; Fig. S7.1). 


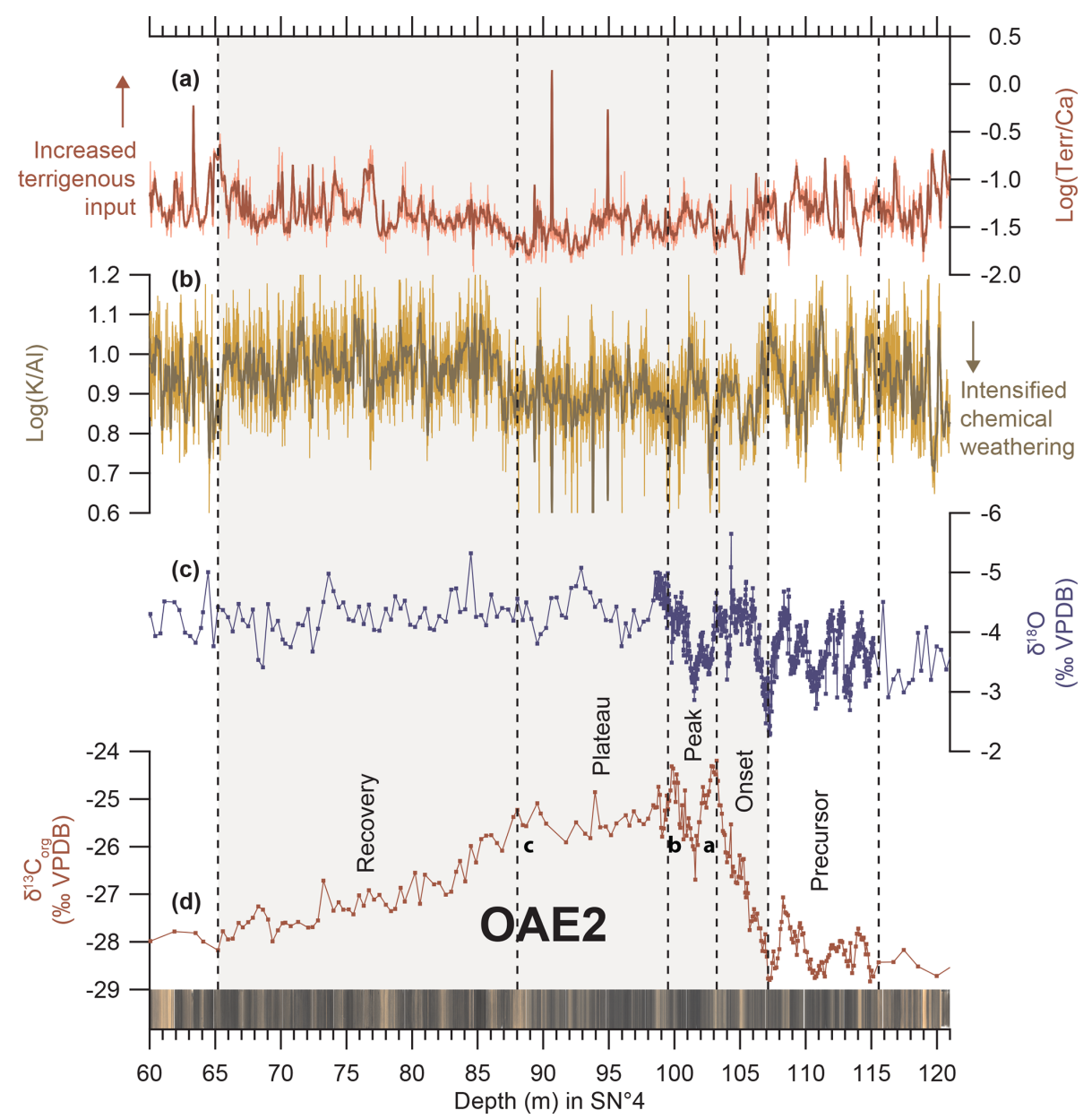

Figure 2. Line scan photographs, stable isotope and XRF scanning elemental records spanning OAE2 in Tarfaya Basin Core $\mathrm{SN}^{\circ} 4$. (a) $\log (\mathrm{Terr} / \mathrm{Ca})$ from Kuhnt et al. (2017) and Beil et al. (2018). (b) $\log (\mathrm{K} / \mathrm{Al})$ from Kuhnt et al. (2017) and Beil et al. (2018). (c) $\delta^{13} \mathrm{O}$ and (d) $\delta^{13} \mathrm{C}_{\text {org }}$ from Kuhnt et al. (2017) and Beil et al. (2018); a-c indicate prominent maxima following Voigt et al. (2007).

\subsection{Phosphorus and organic carbon accumulation rates in Core $\mathrm{SN}^{\circ} 4$}

Bulk sediment mass accumulation rates (MARs) were calculated by multiplication of linear sedimentation rates (LSRs; derived from the age model of Core $\mathrm{SN}^{\circ} 4$ ) with an average dry bulk density (DBD) of $2.1 \mathrm{~g} \mathrm{~cm}^{-3}$. The mean density for the interval encompassing OAE2 (600-2000 kyr) in neighbouring Core S13 (Meyers et al., 2012a) is $2.08 \mathrm{~g} \mathrm{~cm}^{-3}$ (SD $0.12 \mathrm{~g} \mathrm{~cm}^{-3}$ ). Phosphorus accumulation rates (PARs) were calculated by multiplying MAR with phosphorus concentrations from discrete measurements. Organic carbon accumulation rates (TOCARs) were calculated using the organic carbon concentrations from Kuhnt et al. (2017) and Beil et al. (2018).

\section{Results}

\subsection{Temporal evolution of bulk carbonate and organic carbon $\delta^{13} \mathrm{C}$ across OAE1a and OAE2}

The high-resolution $\delta^{13} \mathrm{C}$ record of OAE1a in Core LB3LB1 allowed for correlation with the Aptian isotope stages C2 to C8 proposed by Menegatti et al. (1998). We also identified prominent carbon isotope maxima a-c (following Voigt et al., 2007) in the $\mathrm{SN}^{\circ} 4$ record of OAE2. We determined five phases (precursor, onset, peak, plateau and recovery) in the $\delta^{13} \mathrm{C}$ records of both OAE1a and OAE2 (Figs. 2, 3 and Sect. S8). The interval preceding both OAEs is characterized by a long-term mean without discernible trends and low variability. A precursor phase of two to four distinct $\delta^{13} \mathrm{C} \mathrm{min}$ ima (negative excursions) precedes the onset of the positive carbon isotope excursion (segment $\mathrm{C} 3$ of the Aptian carbon isotope curve of Menegatti et al., 1998). The onset phase encompasses the entire interval of increasing $\delta^{13} \mathrm{C}$ towards the first prominent peak (peak a of OAE2 following Voigt et al., 


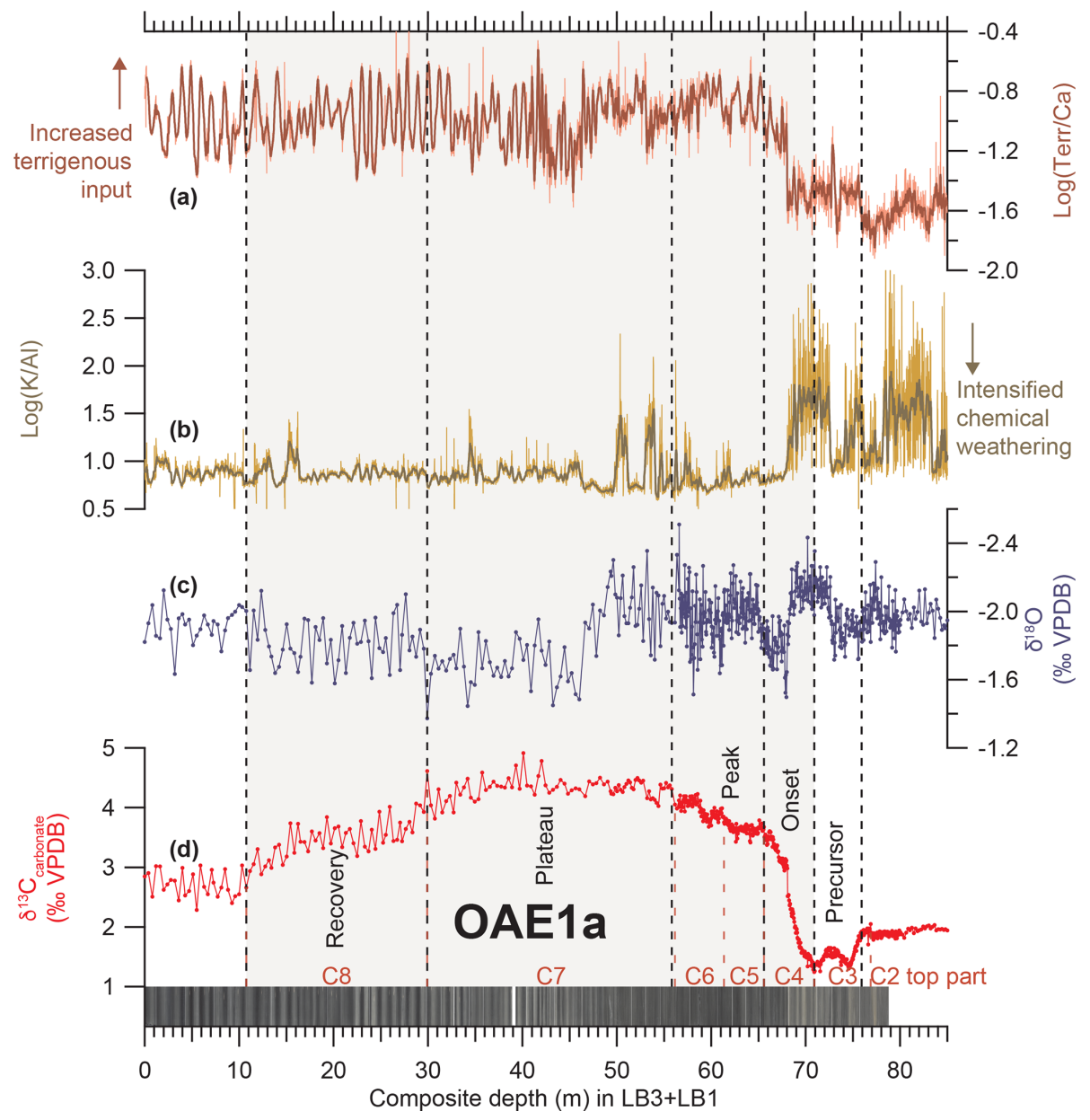

Figure 3. Line scan photographs, stable isotope and XRF scanning elemental records spanning OAE1a from La Bédoule Cores LB3-LB1.

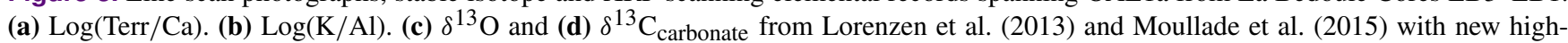
resolution isotope data from this study. The boundaries between individual phases (precursor, onset, peak, plateau, recovery) of OAE1a are indicated by dashed black lines. Carbon isotope stages C2-C8 of Menegatti et al. (1998) are indicated by red lines.

2007). This interval corresponds to segment $C 4$ of the Aptian carbon isotope curve of Menegatti et al., 1998. The peak phase is defined as the interval starting with maximal values (first peak) to the end of the second peak (peak b of OAE2 following Voigt et al., 2007). A characteristic plateau phase (interval of relatively constant $\delta^{13} \mathrm{C}$ ) follows the second peak of the carbon isotope excursions (C6 and lower part of $\mathrm{C} 7$ of Menegatti et al., 1998). The recovery phase encompasses the return of $\delta^{13} \mathrm{C}$ values to background levels following the OAE excursions (upper part of C7 and C8 of Menegatti et al., 1998).

The $\delta^{13} \mathrm{C}$ decreases during the precursor phase have comparable amplitudes, with $0.7 \%$ for OAE1a and $0.4 \%$ for OAE2 (Figs. 2 and 3). The most positive values of the OAE2 $\delta^{13} \mathrm{C}$ isotope excursion are reached at the first peak (peak a following Voigt et al., 2007) at $103.22 \mathrm{~m}$ with $-24.2 \%$ o. By contrast, values continue to increase during OAE1a, with the highest values of $4.9 \%$ o during the plateau stage at $40.11 \mathrm{~m}$.
The difference between the last minimum of the precursor phase and the first maximum (peak a for OAE2) of the peak phase is $2.4 \%$ for the carbonate $\delta^{13} \mathrm{C}$ record of OAE1a and $4.6 \%$ for the organic carbon $\delta^{13} \mathrm{C}$ record of OAE2. Considering the differing trend of OAE1a, with further increases during the plateau stage, the total amplitude of OAE1a is $3.6 \%$. Differences in mean values between the background levels before and after the OAE are $0.3 \%$ for OAE2 (from $-28.5 \%$ (SD $0.3 \%$ o) before to $-28.2 \%$ (SD $0.2 \%$ ) after OAE2) and $0.8 \%$ for OAE1a (from $1.9 \%$ (SD $0.1 \%$ ) before to $2.7 \%$ (SD $0.2 \%$ ) after OAE1a), indicating a general increase in background $\delta^{13} \mathrm{C}$ after the OAEs.

\subsection{Temporal evolution of bulk carbonate $\delta^{18} \mathrm{O}$ across OAE1a and OAE2}

The $\delta^{18} \mathrm{O}$ curves share common trends, except for the cyclic lithological changes in the upper part of the sedimentary record of OAE1a in LB3. Transient cooling events, identi- 
fied by $\delta^{18} \mathrm{O}$ increases in LB3-LB1 and $\mathrm{SN}^{\circ} 4$, occur during the early phases of both OAE1a and OAE2 (Figs. 2, 3 and Sect. S9). A first prominent cooling event prior to the onset of OAE2 in Core $\mathrm{SN}^{\circ} 4$ (Kuhnt et al., 2017), which is not identified at other localities, was probably associated with local upwelling of cooler deepwater masses in the Tarfaya Basin. Cooling during OAE2 occurred in three main steps starting within the onset phase of the positive carbon isotope excursion. The most intense cooling, associated with the Plenus Cold Event, occurred during the peak phase of the excursion (in the trough between the $\delta^{13} \mathrm{C}$ peaks a and $\mathrm{b}$ ). The Plenus Cold Event is globally recorded (e.g. Forster et al., 2007; Sinninghe Damsté et al., 2010; Jarvis et al., 2011; Jenkyns et al., 2017) and coincided with the invasion of boreal species in the European Chalk Sea (Gale and Christensen, 1996; Voigt et al., 2003), the extinction of the planktic foraminifer Rotalipora cushmani (e.g. Kuhnt et al., 2017) and reoxygenation of bottom water masses (e.g. Eicher and Worstell, 1970; Kuhnt et al., 2005; Friedrich et al., 2006). OAE1a shows a similar response of global temperatures to enhanced organic carbon burial (Kuhnt et al., 2011; Jenkyns, 2018): the main $\delta^{18} \mathrm{O}$ increase during the latter part of segment $\mathrm{C} 4$ in the $\delta^{13} \mathrm{C}$ curve of Meneghatti et al. (1998) also occurs during the onset phase. A further cooling event within segment C6 follows transient warming during the peak phase. Jenkyns (2018) recognized these transient coolings, also recorded in the northeastern Atlantic Ocean (Naafs and Pancost, 2016), Italy (Bottini et al., 2015), Turkey (Hu et al., 2012) and in the Pacific Ocean (Dumitrescu et al., 2006), as global events. Similarities in the $\delta^{18} \mathrm{O}$ records across both OAEs imply a similar response of the ocean-climate system to lowered atmospheric $p \mathrm{CO}_{2}$ levels due to excess carbon drawdown associated with the burial of a vast amount of organic material on a global scale.

\subsection{Regional differences in terrigenous input during OAE1a and OAE2}

The different paleogeographic settings and depositional environments of the Tarfaya Basin (Core $\mathrm{SN}^{\circ} 4$ ) and South Provence Basin (Cores LB1 and LB3) result in important differences in terrigenous sediment input. The XRF-derived $\log ($ Terr/Ca) (Fig. 2) in the Tarfaya Basin exhibits low variability throughout, with the lowest values during OAE2. By contrast, $\log$ (Terr/Ca) (Fig. 3) shows higher-amplitude variability during OAE1a. A major increase in $\log (\mathrm{Terr} / \mathrm{Ca})$ from -1.69 to -0.87 during the onset of OAE1a (68.09-67.99 m) indicates either a decrease in carbonate deposition or an increase in terrigenous input. Following this increase, the NGR and $\log (\mathrm{Terr} / \mathrm{Ca})$ records exhibit high-amplitude and high-frequency variability during C4 to C6 (26-23.29 m) and during the latter part of $\mathrm{C} 7$ and $\mathrm{C} 8(49.7-0 \mathrm{~m})$ (Figs. 3, 4 and S3.1).

\subsection{Duration of OAE1a estimated from time series analysis of NGR and XRF scanner data}

The spliced NGR record of LB1 and LB3 across OAE1a was subdivided into five intervals of relatively consistent orbital periodicities (N1 to N5) based on EHA (Fig. 4, Sect. S3). The recognition of cyclic patterns in the NGR record during OAEla allowed for the correlation of major frequencies with orbital periodicities (Laskar et al., 2004, 2011a, b) and the calculation of mean sedimentation rates (Figs. 4 and S3.2, Tables S3.3 and S5.2). Comparison with durations proposed by Malinverno et al. (2010) and Scott (2016) for the different C stages of Menegatti et al. (1998) is shown in Table 2. A strong response to variations in obliquity and precession is evident in the latest part of stage $\mathrm{C} 2$, which precedes the onset of OAE1a (Figs. 4, S3.1 and S3.2). The NGR and $\log ($ Terr/Ca) time series (Figs. 4 and S3.1) also exhibit precession-paced variations during the middle and later part of stages $\mathrm{C} 7$ and $\mathrm{C} 8$, which persist after OAE1a. This trend corresponds to pronounced lithological changes between carbonate-rich and clay-rich beds that are also apparent in the core images and the $\delta^{13} \mathrm{C}_{\text {carbonate }}$ and $\delta^{18} \mathrm{O}$ profiles (Fig. 3).

Sedimentation rates (Table S3.3) increase from C3 and C4 $\left(1.4 \mathrm{~cm} \mathrm{kyr}^{-1}\right)$ to the recovery phase $\mathrm{C} 8\left(5.1 \mathrm{~cm} \mathrm{kyr}^{-1}\right)$. The relatively stable ratio between terrigenous and carbonate content $(\log (\mathrm{Terr} / \mathrm{Ca})$ suggests a continuous increase in both carbonate and terrigenous input (Fig. 3).

\subsection{Duration of OAE2 estimated from time series analysis of NGR data}

EHA of NGR data reveals a marked response to obliquity (mainly o1, $48 \mathrm{kyr}$ ) and short eccentricity (e2 and e3; $100 \mathrm{kyr}$ ) during the positive $\delta^{13} \mathrm{C}$ excursion (Fig. 5). Following this interpretation, the $\delta^{13} \mathrm{C}$ excursion of OAE2 in Core $\mathrm{SN}^{\circ} 4$ lasted for $\sim 790 \mathrm{kyr}$ including the recovery phase ( $\sim 360 \mathrm{kyr}$ without the recovery phase). The response to orbital forcing was more pronounced during the peak phase ( $\sim 90 \mathrm{kyr})$ and the recovery phase $(\sim 440 \mathrm{kyr})$ than during the plateau phase $(\sim 200 \mathrm{kyr})$. Sedimentation rates before the onset of OAE2 were $8.2 \mathrm{~cm} \mathrm{kyr}^{-1}$, dropping to $4.1 \mathrm{~cm} \mathrm{kyr}^{-1}$ during the positive $\delta^{13} \mathrm{C}$ excursion and recovering to $\sim$ $8 \mathrm{~cm} \mathrm{kyr}^{-1}$ in the upper part of the plateau phase (Fig. S4.1), which is comparable to levels prior to OAE2.

Four $\delta^{13} \mathrm{C}_{\text {org }}$ minima (precursor phase) occur over a period of $\sim 130 \mathrm{kyr}$ prior to the positive $\delta^{13} \mathrm{C}$ excursion of OAE2 (Figs. 2, S4.1). The onset phase of OAE2 ( $70 \mathrm{kyr})$, defined as the interval between the centre of the last $\delta^{13} \mathrm{C}_{\text {org }}$ minimum and the first $\delta^{13} \mathrm{C}_{\text {org }}$ maximum of OAE2, is subdivided into three phases: the initial steep increase lasted $\sim 31 \mathrm{kyr}$, the intermediate plateau $\sim 14 \mathrm{kyr}$ and the final rise to the first peak (peak a of Voigt et al., 2007) of the carbon isotope excursion $\sim 24 \mathrm{kyr}$. The time interval between the two maxima in $\delta^{13} \mathrm{C}_{\text {org }}$ (peak phase) was $\sim 90 \mathrm{kyr}$. The duration of 
Table 2. Durations and sedimentation rates for Aptian C stages (following Menegatti et al., 1998) in La Bédoule Core LB3-LB1 and comparison with durations from Malinverno et al. (2010) and Scott (2016).

\begin{tabular}{|c|c|c|c|c|c|c|c|}
\hline C stage & $\begin{array}{r}\text { Top in } \\
\text { LB3-LB1 } \\
\text { (m) }\end{array}$ & $\begin{array}{r}\text { Base in } \\
\text { LB3-LB1 } \\
\text { (m) }\end{array}$ & Segment & $\begin{array}{r}\text { Duration } \\
\text { (kyr) }\end{array}$ & $\begin{array}{l}\text { Mean sed. rate } \\
\text { during } C \text { stage } \\
\quad\left(\mathrm{cm} \mathrm{kyr}^{-1}\right)\end{array}$ & $\begin{array}{r}\text { Durations (kyr) } \\
\text { following } \\
\text { Malinverno et al. } \\
(2010)\end{array}$ & $\begin{array}{l}\text { Durations (kyr) } \\
\text { of Scott (2016) }\end{array}$ \\
\hline $\mathrm{C} 8$ & 10.75 & 29.92 & N1 & 377 & 5.09 & & \\
\hline C7 & 29.92 & 56.16 & $\mathrm{~N} 1+\mathrm{N} 2$ & 1343 & 1.95 & 1590 & 990 \\
\hline C6 & 56.16 & 61.35 & $\mathrm{~N} 2+\mathrm{N} 3$ & 315 & 1.65 & 349 & 110 \\
\hline C5 & 61.35 & 65.58 & N3 & 281 & 1.50 & 510 & 210 \\
\hline $\mathrm{C} 4$ & 65.58 & 70.91 & $\mathrm{~N} 4$ & 388 & 1.37 & 239 & 160 \\
\hline $\mathrm{C} 3$ & 70.91 & 76.87 & $\mathrm{~N} 4$ & 434 & 1.37 & 46.7 & 80 \\
\hline
\end{tabular}

Table 3. Durations of individual phases for OAE2 in Tarfaya Basin Core $\mathrm{SN}^{\circ} 4$ and comparison with Li et al. (2017b) and Gangl et al. (2019).

\begin{tabular}{llll}
\hline Phases & $\begin{array}{l}\text { SN }{ }^{\circ} \text { (Tarfaya Basin, } \\
\text { SW Morocco; this study) }\end{array}$ & $\begin{array}{l}\text { Gongzha section } \\
\text { (Tibet; Li et al., 2017b) }\end{array}$ & $\begin{array}{l}\text { Sawpit Gully section } \\
\text { (New Zealand; Gangl et al., 2019) }\end{array}$ \\
\hline Precursor & $126 \mathrm{kyr}$ (last two prominent minima: $75 \mathrm{kyr})$ & $50 \pm 25 \mathrm{kyr}$ (stage 2) & $50 \mathrm{kyr}$ \\
Onset & $68 \mathrm{kyr}$ & $110 \pm 25 \mathrm{kyr}$ (stage 3a) & $30 \pm 13 \mathrm{kyr}$ \\
Peak & $86 \mathrm{kyr}$ & $170 \pm 25 \mathrm{kyr}$ (stages 3b+c) & $200 \pm 25 \mathrm{kyr}$ \\
Plateau & $204 \mathrm{kyr}$ & $370 \pm 25 \mathrm{kyr}$ (stage 4) & $660 \pm 25 \mathrm{kyr}$ \\
Recovery & $435 \mathrm{kyr}$ & $170 \pm 25 \mathrm{kyr}$ (stage 5) & $40 \pm 25 \mathrm{kyr}$ \\
\hline
\end{tabular}

the plateau phase, defined as the period between the second maximum and the end of the $\delta^{13} \mathrm{C}_{\text {org }}$ plateau, was $\sim 200 \mathrm{kyr}$. The recovery phase between the end of the plateau and the return to background values after OAE2 lasted $\sim 440 \mathrm{kyr}$. A comparison with durations proposed by Li et al. (2017b) and Gangl et al. (2019) is provided in Table 3.

\subsection{Comparison of the durations of OAE1a and OAE2}

The precursor phase of OAE1a (C3 of Menegatti et al., 1998), which consists of an extended interval of low $\delta^{13} \mathrm{C}_{\text {carbonate }}(<1.75 \%$ o $)$ and encompasses two prominent $\delta^{13} \mathrm{C}$ minima $(<1.5 \% o)$, lasted $\sim 434 \mathrm{kyr}$. The precursor phase of OAE2 is characterized by four nearly equally spaced $\delta^{13} \mathrm{C}_{\text {org }}$ minima $(<28.5 \%$ o $)$ and lasted $\sim 126 \mathrm{kyr}$. The last two prominent minima immediately precede the onset of OAE2 and lasted for $\sim 75 \mathrm{kyr}$. The onset phase of the positive isotope excursions had a duration of $\sim 388 \mathrm{kyr}$ for OAE1a (C4 of Menegatti et al., 1998) and $\sim 68 \mathrm{kyr}$ for OAE2. The peak phase lasted $\sim 596 \mathrm{kyr}$ in OAE1a (C5 and C6) and $\sim$ $86 \mathrm{kyr}$ in OAE2, the plateau phase extended over $\sim 1343 \mathrm{kyr}$ in OAE1a (C7) and $204 \mathrm{kyr}$ in OAE2, and the final recovery phase had a duration of $\sim 377 \mathrm{kyr}$ for OAE1a (C8) and $\sim 435 \mathrm{kyr}$ for OAE2. The precursor, onset and peak phases were consistently $\sim 5$ times longer in OAE1a than in OAE2, whereas the plateau phase was more than $\sim 7$ times longer. The recovery phases had the same duration for both OAEs, taking into account uncertainties in defining change points at the end of the $\delta^{13} \mathrm{C}$ excursion.

\subsection{Sedimentary phosphorus}

Total phosphorus $\left(\mathrm{P}_{\text {total }}\right)$ concentrations in Core $\mathrm{SN}^{\circ} 4$ (Fig. 6) are overall below $5 \mathrm{mg} \mathrm{g}^{-1}$, except during two periods of enrichment peaking at $220.19 \mathrm{~m}$ with $16.61 \mathrm{mg} \mathrm{g}^{-1}$ and at $104.4 \mathrm{~m}$ with $7.53 \mathrm{mg} \mathrm{g}^{-1}$. Corresponding peaks in $\mathrm{P}_{\text {total }} / \mathrm{Al}$ give a weight ratio of 1.07 at $220.19 \mathrm{~m}$ and 1.20 at $104.4 \mathrm{~m}$. Concentrations and variability of $\mathrm{P}_{\text {total }}$ are low in the lowermost (305-267 m) and uppermost (67.51-42.11 m) parts of the studied interval, with means of $0.54 \mathrm{mg} \mathrm{g}^{-1}$ (SD $0.19 \mathrm{mg} \mathrm{g}^{-1}$ ) and $0.86 \mathrm{mg} \mathrm{g}^{-1}$ (SD $0.3 \mathrm{mg} \mathrm{g}^{-1}$ ), respectively. The origin of the phosphorus is difficult to assess, as the different species extracted are defined by the CONVEX method (Oxmann et al., 2008). Earlier studies found finely distributed fish debris and fecal pellets in Cenomanian sediments of the Tarfaya Basin (e.g. El Albani et al., 1999) partially reprecipitated as phosphate nodules during early diagenesis (e.g. Leine, 1986; Kuhnt et al., 1997). Phosphatic particles were not observed on the core surfaces and were not apparent in the XRF data from Core $\mathrm{SN}^{\circ} 4$. They were only encountered as minor components in the residues of micropaleontological samples. The dissolution of phosphorus fixed in iron-aluminium crusts and the degradation of organic matter followed by reprecipitation as calcium-bound phosphorus further complicate the reconstruction of the initial source of phosphorus. 

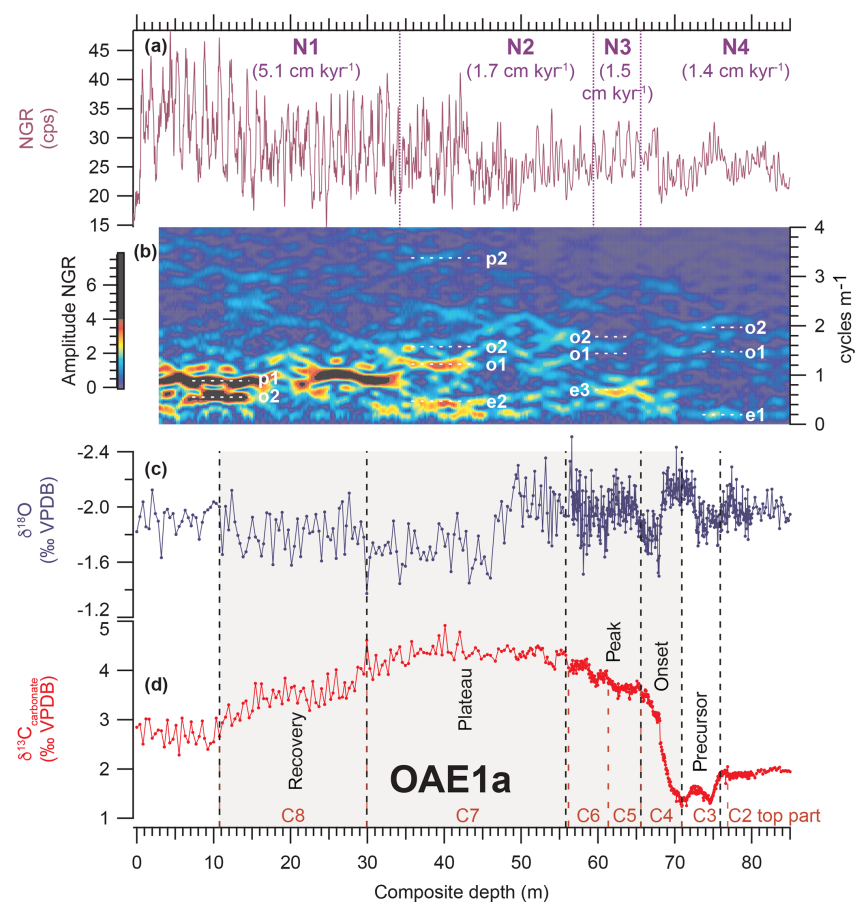

Figure 4. Identification of orbital periodicities across OAE1a using evolutive harmonic analysis (EHA) of natural gamma ray (NGR) data in La Bédoule Cores LB3-LB1. (a) NGR; purple dashed lines mark boundaries from segment N1 to N4 (Sect. S3 and Fig. S3.2); mean sedimentation rates given in brackets. (b) EHA plot of NGR; orbital periodicities are indicated by white dashed lines; eccentricity e1 (404 kyr), e2 (124 kyr) and e3 (95 kyr), obliquity o1 (47 kyr) and $\mathrm{o} 2$ (37 kyr), precession p1 (22 kyr) and p2 (18 kyr) (Table S5.2). (c) $\delta^{18} \mathrm{O}$ and (d) $\delta^{13} \mathrm{C}_{\text {carbonate from Lorenzen et al. (2013) and }}$ Moullade et al. (2015) with new high-resolution isotope data from this study. Carbon isotope stages C2-C8 of Menegatti et al. (1998) are indicated by red dashed lines. Individual phases (precursor, onset, peak, plateau, recovery) of OAE1a are separated by black dashed lines. Note: the EHA colour scheme is limited to $50 \%$ of the maximum amplitude to enhance visibility in the lower part of the core.

\subsection{Phosphorus speciation}

Concentrations of reactive phosphorus ( $\mathrm{P}_{\text {react }}$; Fig. 7) in Core $\mathrm{SN}^{\circ} 4$, calculated by summing up $\mathrm{Al} / \mathrm{Fe}$ - and $\mathrm{Ca}$-bound phosphorus, are on average $\sim 89 \%$ of the total phosphorus $\left(\mathrm{P}_{\text {total }}\right.$; Figs. 6 and S7.1) measured with ICP-OES. Organic-matterbound phosphorus was not considered due to methodological limitations (Golterman, 2001) and to remineralization and reprecipitation (sink switching) into more stable $\mathrm{Al} / \mathrm{Fe}$ and Ca-bound phosphorus species during early diagenesis. Differences between $\mathrm{P}_{\text {react }}$ and $\mathrm{P}_{\text {total }}$ are caused by nonextractable phosphorus bound in insoluble minerals or adhesively bound phosphorus extracted and discarded during the first step with $\mathrm{KCl}$ and EtOH (Fig. S6.1).

Concentrations of phosphorus bound to aluminium or iron oxyhydroxides (AlFeP; Fig. 6) are low (me-

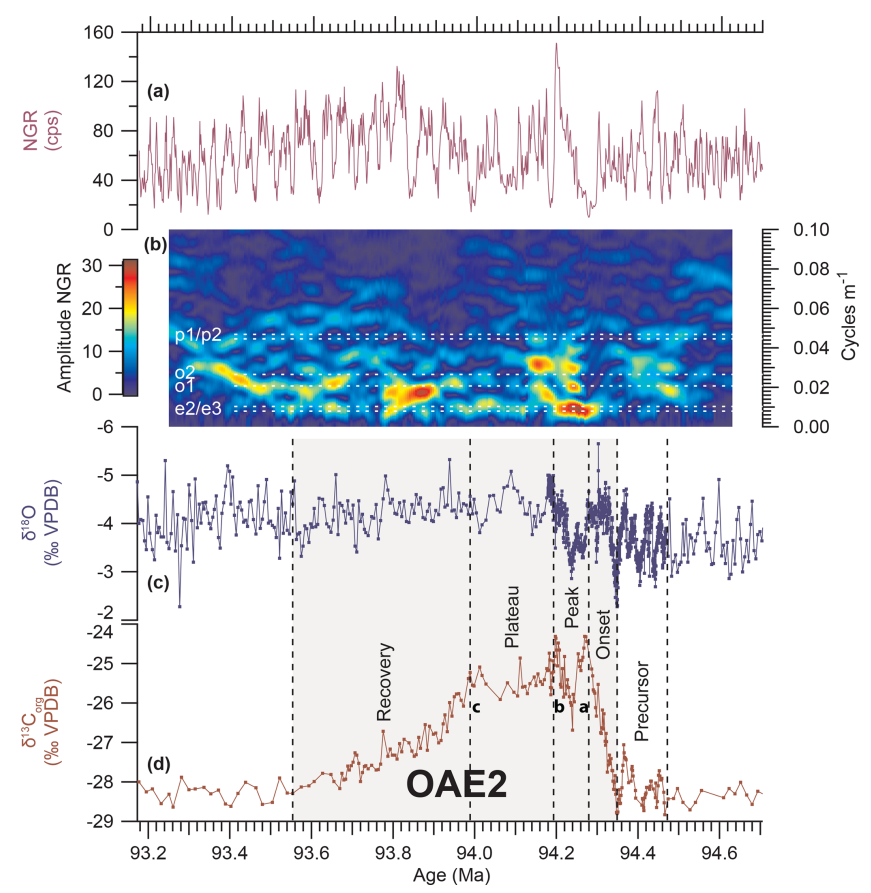

Figure 5. Identification of orbital periodicities over OAE2 from evolutive harmonic analysis (EHA) of natural gamma ray (NGR) data in Tarfaya Basin Core $\mathrm{SN}^{\circ}$ 4. (a) NGR. (b) EHA plot of NGR; orbital periodicities are indicated by white dashed lines: eccentricity e2 (127 kyr) and e3 (97 kyr), obliquity o1 (48 kyr) and o2 (38 kyr), precession p1 (22 kyr) and p2 (18 kyr) (Table S5.3). (c) $\delta^{18} \mathrm{O}$ and (d) $\delta^{13} \mathrm{C}_{\mathrm{org}}$ from Kuhnt et al. (2017) and Beil et al. (2018); a-c indicate prominent maxima following Voigt et al. (2007).

dian $\quad 0.014 \mathrm{mg} \mathrm{g}^{-1}$ ). Increased concentrations (mean $0.027 \mathrm{mg} \mathrm{g}^{-1}$ ) are determined for the lowermost interval between 305 and $272.58 \mathrm{~m}$, followed by an interval with a lower average concentration (mean $0.014 \mathrm{mg} \mathrm{g}^{-1}$ ) and lower variability (SD $0.006 \mathrm{mg} \mathrm{g}^{-1}$ ) until $72.09 \mathrm{~m}$. The uppermost interval is again characterized by increased variability (SD $0.008 \mathrm{mg} \mathrm{g}^{-1}$ ). Calcium-bound phosphorus (CaP; Fig. 6) is the dominant species in the studied interval of Core $\mathrm{SN}^{\circ} 4$. Concentrations are below $4 \mathrm{mg} \mathrm{g}^{-1}$, except for two periods of enrichment peaking at 220.19 and $104.4 \mathrm{~m}$ with 15.76 and $6.62 \mathrm{mg} \mathrm{g}^{-1}$, respectively. Both maxima coincide with the maximum enrichment of total phosphorus. The redox influence on $\mathrm{Al} / \mathrm{Fe}$-bound phosphorus in Core $\mathrm{SN}^{\circ} 4$ is addressed in the Sect. S10.

The atomic ratios of $\mathrm{C}_{\text {org }}$ and $\mathrm{N}_{\text {total }}$ against $\mathrm{P}_{\text {react }}$ show very similar trends except for the lower part between 305.77 and $258.35 \mathrm{~m}$ that is characterized in $\mathrm{N}_{\text {total }} / \mathrm{P}_{\text {react }}$ by increased values (median 5.9) and in $\mathrm{C}_{\text {org }} / \mathrm{P}_{\text {react }}$ by low values and low variability (median 77.6, SD 34.9), albeit in an interval with low resolution (Fig. 7). Afterwards both ratios show similar characteristics of low values (median of $\mathrm{C}_{\text {org }} / \mathrm{P}_{\text {react }} 89.1$ and of $\mathrm{N}_{\text {total }} / \mathrm{P}_{\text {react }} 3.5$ ) and low variability (SD of $\mathrm{C}_{\text {org }} / \mathrm{P}_{\text {react }} 67.1$ and of $\mathrm{N}_{\text {total }} / \mathrm{P}_{\text {react }} 1.9$ ) un- 


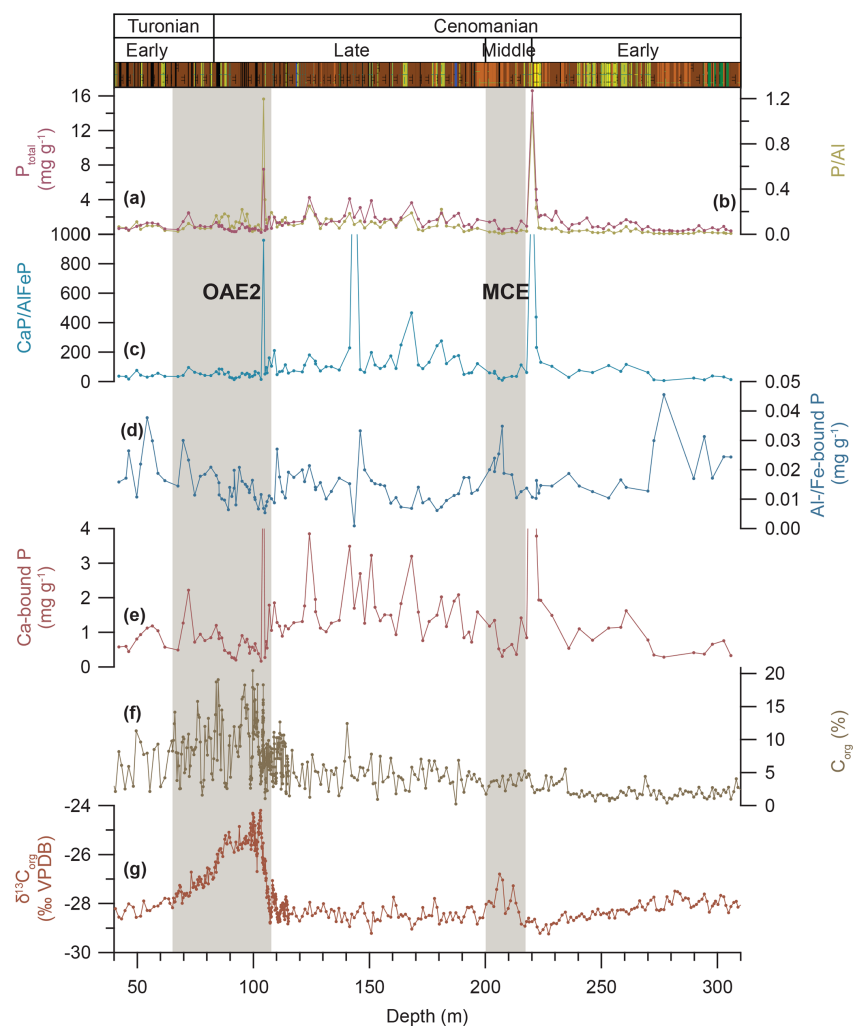

Figure 6. Phosphorus concentration and speciation in Tarfaya Basin Core $\mathrm{SN}^{\circ}$ 4. (a) Concentration of total phosphorus ( $\left.\mathrm{P}_{\text {total }}\right)$. (b) Ratio of total phosphorus to aluminium $(\mathrm{P} / \mathrm{Al})$ measured on bulk sediment. (c) Ratio of calcium- to aluminium- and ironbound phosphorus $(\mathrm{CaP} / \mathrm{AlFeP})$. (d) Concentration of aluminiumand iron-bound phosphorus ( $\mathrm{Al} / \mathrm{Fe}-$ bound $\mathrm{P}$ ). (e) Concentration of calcium-bound phosphorus (Ca-bound P). (f) Concentration of organic carbon $\left(\mathrm{C}_{\text {org }}\right)$ and $(\mathrm{g}) \delta^{13} \mathrm{C}_{\text {org }}$ from Kuhnt et al. (2017) and Beil et al. (2018).

til $104.4 \mathrm{~m}$, punctuated by short-lived maxima during the MCE (average of $\mathrm{C}_{\text {org }} / \mathrm{P}_{\text {react }} 170$ and of $\mathrm{N}_{\text {total }} / \mathrm{P}_{\text {react }} 7.5$ ). OAE2 is again characterized by markedly increased ratios (maxima of $\mathrm{C}_{\text {org }} / \mathrm{P}_{\text {react }} 1123.8$ and of $\mathrm{N}_{\text {total }} / \mathrm{P}_{\text {react }} 29.6$ ), and the uppermost part exhibits increased values (median of $\mathrm{C}_{\text {org }} / \mathrm{P}_{\text {react }} 242.6$ and of $\mathrm{N}_{\text {total }} / \mathrm{P}_{\text {react }}$ 7.3). The ratio of CONVEX-extracted AlFeP to $\mathrm{P}_{\text {total }}$ (Fig. 7) shows increased values (mean 0.058) in the lower part between 305 and $272.58 \mathrm{~m}$, followed by low ratios (mean 0.014 ) to the top of the sampled interval in Core $\mathrm{SN}^{\circ} 4$.

\subsection{Temporal changes in P-species concentrations and accumulation rates}

Two maxima in $\mathrm{P}_{\text {total }}$ in the Cenomanian interval of Core $\mathrm{SN}^{\circ} 4$ coincide with maxima in $\mathrm{P}_{\text {total }} / \mathrm{Al}$ (Fig. 6). The more prominent of these phosphorus enrichments (peaking at $220.19 \mathrm{~m}$ ) precedes the onset of the MCE by $\sim 3.04 \mathrm{~m}$. The second maximum at $104.4 \mathrm{~m}$ occurs during the onset phase

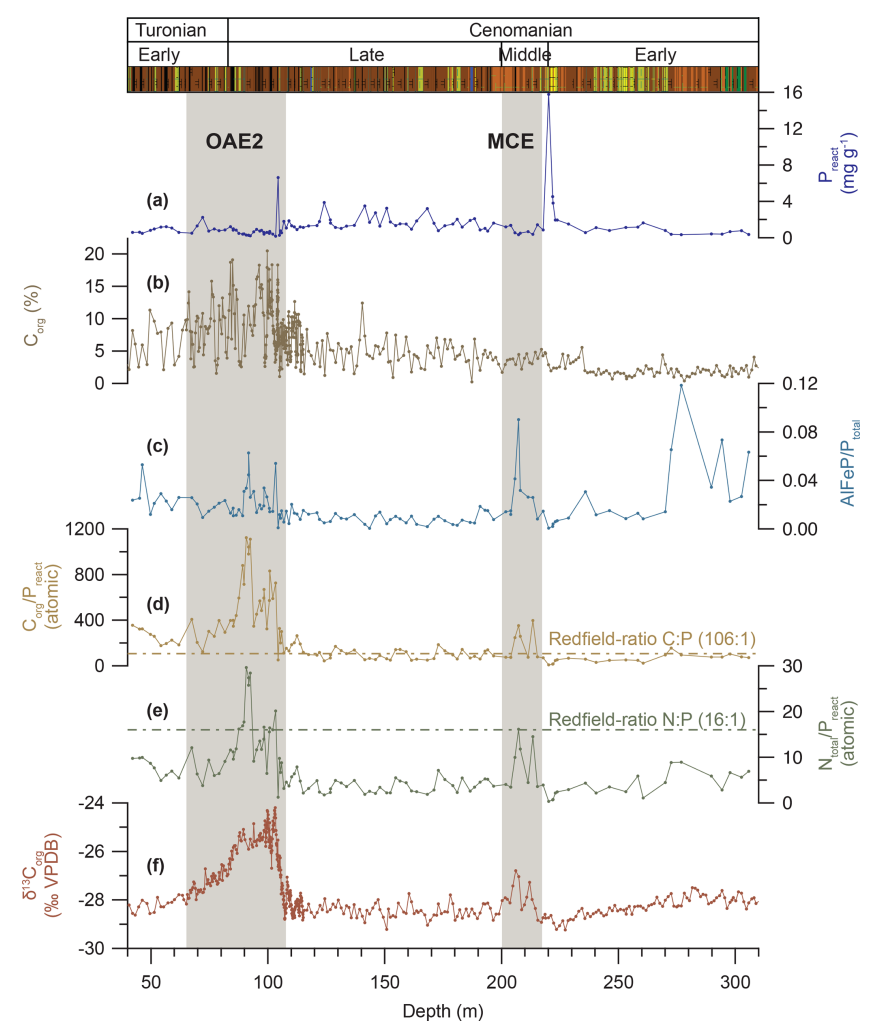

Figure 7. Phosphorus speciation in Tarfaya Basin Core $\mathrm{SN}^{\circ} 4$. (a) Concentration of reactive phosphorus $\left(\mathrm{P}_{\text {react }}\right)$ calculated as the sum of $\mathrm{Al} / \mathrm{Fe}$ - and Ca-bound $\mathrm{P}$. (b) Concentration of organic carbon $\left(\mathrm{C}_{\mathrm{org}}\right)$. (c) Ratio of aluminium- and iron-bound phosphorus to total phosphorus $\left(\mathrm{AlFeP} / \mathrm{P}_{\text {total }}\right)$. (d) Atomic ratio of organic carbon to reactive phosphorus $\left(\mathrm{C}_{\text {org }} / \mathrm{P}_{\text {react }}\right)$ with Redfield ratio $106: 1$ indicated as a dashed line. (e) Atomic ratio of total nitrogen to reactive phosphorus $\left(\mathrm{N}_{\text {total }} / \mathrm{P}_{\text {react }}\right)$ with Redfield ratio $16: 1$ indicated as a dashed line. (f) $\delta^{13} \mathrm{C}_{\text {org }}$ from Kuhnt et al. (2017) and Beil et al. (2018).

of OAE2 and coincides with a transient $\delta^{13} \mathrm{C}$ minimum, approximately halfway towards the first $\delta^{13} \mathrm{C}_{\text {org }}$ maximum at $103.22 \mathrm{~m}$ (Figs. 6 and S9.1).

The ratio of $\mathrm{Ca}$-bound to $\mathrm{Al} / \mathrm{Fe}$-bound phosphorus (Fig. 6) is characterized by three prominent peaks at $220.19,143.51$ and $104.40 \mathrm{~m}$. The maxima at 220.19 and $104.40 \mathrm{~m}$ also exhibit high $\mathrm{P}_{\text {total }}$ concentrations and $\mathrm{P}_{\text {total }} / \mathrm{Al}$ maxima. The first peak at $220.19 \mathrm{~m}$ precedes the first $\delta^{13} \mathrm{C}_{\text {org }}$ increase of the MCE, and the second peak at $104.4 \mathrm{~m}$ occurs within the onset phase of the $\delta^{13} \mathrm{C}_{\mathrm{org}}$ excursion of OAE2. Both peaks of $\mathrm{CaP} / \mathrm{AlFeP}$ and $\mathrm{P}_{\text {total }}$ coincide with minima in the $\mathrm{C}_{\text {org }} / \mathrm{P}_{\text {total }}$ ratio (Fig. S7.1), suggesting an inorganic source for phosphorus or enhanced recycling of organic carbon and reprecipitation of the organic-bound phosphorus as Ca-bound phosphorus.

The increase in the atomic $\mathrm{C}_{\text {org }} / \mathrm{P}_{\text {total }}$ ratio (Fig. S7.1) during OAE2 post-dates the increase in the atomic $\mathrm{C}_{\text {org }} / \mathrm{N}_{\text {total }}$ ratio, interpreted by Beil et al. (2018) as enhanced cycling of 
nitrogen-rich organic matter within a dysoxic or anoxic water column. The increase in $\mathrm{C}_{\text {org }} / \mathrm{P}_{\text {total }}$ starts immediately above the prominent peaks in total and in $\mathrm{Ca}-$ and $\mathrm{Al} / \mathrm{Fe}$-bound phosphorus, and it coincides with the first $\delta^{13} \mathrm{C}_{\text {org }}$ maximum of OAE2 (Figs. 6 and 7). The highest $\mathrm{C}_{\text {org }} / \mathrm{P}_{\text {total }}$ ratio is determined at $90.78 \mathrm{~m}$ within the plateau phase of OAE2. This peak coincides with minima in $\mathrm{P}_{\text {total }}$ and $\mathrm{P}_{\text {total }} / \mathrm{Al}$, implying remobilization either synsedimentary due to preferential recycling of phosphorus in the water column and/or in the sediment. This decrease in $\mathrm{P}_{\text {total }}$ content is paralleled by a decrease in $\mathrm{C}_{\text {org }}$ (Fig. 6), suggesting enhanced remobilization of phosphorus as well as organic matter.

The atomic ratios of $\mathrm{C}_{\text {org }} / \mathrm{P}_{\text {react }}$ and $\mathrm{N}_{\text {total }} / \mathrm{P}_{\text {react }}$ (Fig. 7) are always lower than or close to the Redfield ratio $(\mathrm{C}$ : $\mathrm{N}: \mathrm{P}=106: 16: 1$; Redfield, 1958, 1963), except during the MCE and OAE2, when $\mathrm{C}_{\text {org }} / \mathrm{P}_{\text {react }}$ is equal to or higher than $106: 1$ and $\mathrm{N}_{\text {total }} / \mathrm{P}_{\text {react }}$ is close to the predicted ratio of $16: 1$. Both ratios surpass predicted values at the first $\delta^{13} \mathrm{C}_{\text {org }}$ peak of OAE2, decrease slightly during the Plenus Cold Event and show a large increase during the plateau phase. The remaining interval is characterized by increased values above background level as in the lower part of Core $\mathrm{SN}^{\circ} 4$ prior to the onset of OAE2.

Phosphorus accumulation rates (ARs) decline during the onset, peak and plateau phase of OAE2 (Fig. 8), with $\mathrm{P}_{\text {total }} \mathrm{AR}, \mathrm{P}_{\text {react }} \mathrm{AR}$ and $\mathrm{CaP}$ AR declining by $\sim 75 \%$ and AlFeP AR by $\sim 40 \%$. Phosphorus accumulation recovers after the end of the plateau phase and increases for $\mathrm{P}_{\text {total }}$ by $\sim 230 \%$, for $\mathrm{P}_{\text {react }}$ and $\mathrm{CaP}$ by $\sim 250 \%$, and for $\mathrm{AlFeP}$ by $\sim 210 \%$.

\section{Discussion}

\subsection{Influence of paleogeographic setting and weathering regime}

Changes in the weathering regime of the source area during OAE1a, as shown by the XRF-scanner-derived $\log (\mathrm{K} / \mathrm{Al})$, influenced the sedimentary record of Cores LB1 and LB3 (Fig. 3). Increased $\log (\mathrm{K} / \mathrm{Al})$ and higher $\delta^{18} \mathrm{O}$ suggest predominantly physical weathering and/or intensified erosion, characteristic of drier conditions, and/or markedly seasonal rainfall prior to OAE1a (C2 and early C3) (Figs. 3 and 4). A decrease in $\log (\mathrm{K} / \mathrm{Al})$, synchronous with a shift to carbonatedepleted sediments indicated by $\log (\mathrm{Terr} / \mathrm{Ca})$, coincides with an increase in $\delta^{18} \mathrm{O}$ associated with the first transient cold event within the onset phase of OAE1a (C4). This major cooling event in the South Provence Basin was probably of global character (e.g. Jenkyns, 2018). The covariance of $\delta^{18} \mathrm{O}$ and $\log (\mathrm{K} / \mathrm{Al})$, in combination with published palynological and geochemical data (e.g. Masure et al., 1998; Hochuli et al., 1999; Keller et al., 2011; Föllmi, 2012; Cors et al., 2015), suggests that the La Bédoule area was located at the northern edge of the subtropical high-pressure desert belt and shifted into the Northern Hemisphere westerlies with in-

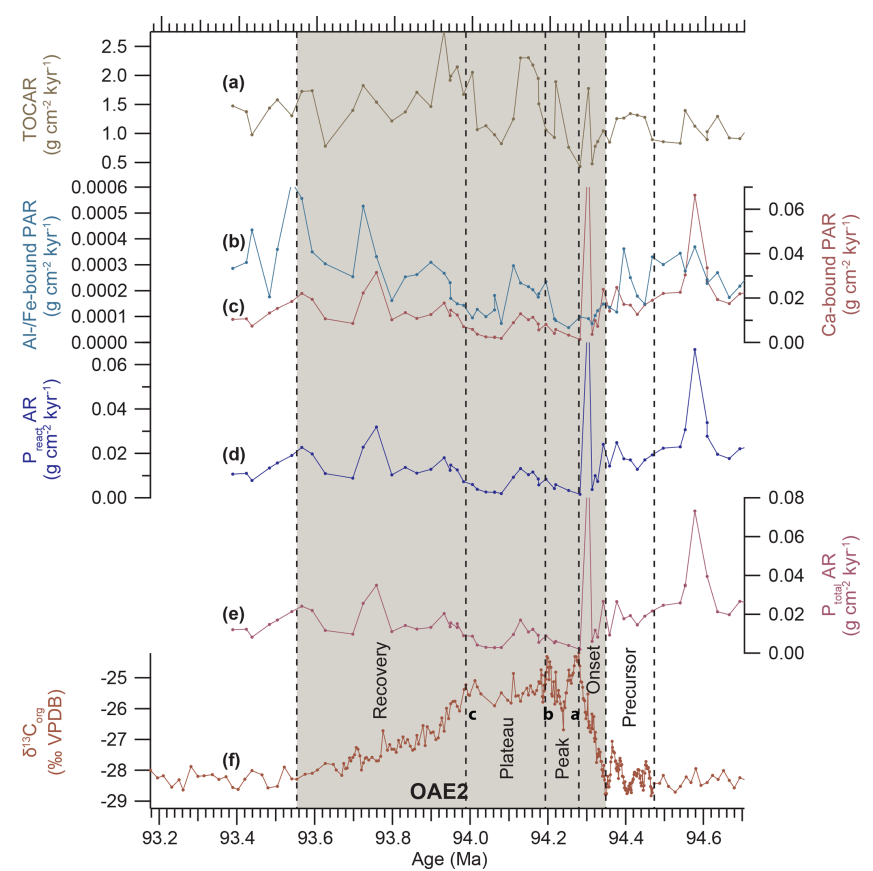

Figure 8. Phosphorus accumulation rates across OAE2 in Tarfaya Basin Core $\mathrm{SN}^{\circ} 4$ (age model based on Meyers et al. 2012a). (a) Accumulation rate of organic carbon (TOCAR). (b) Accumulation rate of aluminium- and iron-bound phosphorus ( $\mathrm{Al} / \mathrm{Fe}$-bound PAR). (c) Accumulation rate of calcium-bound phosphorus (Cabound PAR). (d) Accumulation rate of reactive phosphorus calculated as the sum of $\mathrm{Al} / \mathrm{Fe}$ - and Ca-bound $\mathrm{P}$ ( $\left.\mathrm{P}_{\text {react }} \mathrm{AR}\right)$. (e) Accumulation rate of total phosphorus $\left(\mathrm{P}_{\text {total }} \mathrm{AR}\right)$. (f) $\delta^{13} \mathrm{C}_{\text {org }}$. Stable isotope data and organic carbon concentrations from Kuhnt et al. (2017) and Beil et al. (2018); a-c indicate prominent maxima following Voigt et al. (2007).

creased rainfall during OAE1a. An equatorward contraction of the subtropical high-pressure belt also occurred in East Asia during the mid-Cretaceous warm period (Hasegawa et al., 2012). The paleo-location of La Bédoule (Cores LB1 and LB3) close to $30^{\circ} \mathrm{N}$ (Masse et al., 2000) would predispose the area to latitudinal changes in the Hadley cell with drier conditions in times of an expanded high-pressure belt and increased rainfall resulting from an equatorward contracted Hadley cell. Strengthening fluctuations between drier and wetter climate conditions are recorded during the onset, main and early plateau phase. After a stabilization during the plateau phase, wet conditions prevailed after OAE1a.

The evolution of the weathering regime across OAE2 differed substantially in the Tarfaya Basin (Fig. 2), probably due to the lower paleolatitude and different paleoceanographic setting in a coastal upwelling area. The period prior to OAE2 was characterized by low sea surface temperatures and high mean $\log (\mathrm{K} / \mathrm{Al})$ exhibiting high variability, suggesting orbital forcing of a monsoonal hydrological cycle and weathering regime. A first prominent temperature decrease occurred during the late precursor and early onset phase of OAE2, sim- 
ilar to the global temperature decrease during OAE1a (Fig. 3; Jenkyns, 2018). A shift to lower mean $\log (\mathrm{K} / \mathrm{Al})$, indicative of stronger chemical weathering and/or reduced monsoonal seasonality in the source area, coincided with low sea surface temperatures during the precursor phase and suggests increased upwelling intensity and intensified monsoonal wind forcing. A shift back to higher $\log (\mathrm{K} / \mathrm{Al})$, indicating weaker chemical weathering in the source area, occurred at the end of the plateau phase of OAE2. The main interval of OAE2 (onset, peak and plateau phase) was characterized by intense chemical weathering and a weaker response of the hydrological cycle to orbital forcing, suggesting that the hinterland of the Tarfaya Basin was more or less permanently under the influence of tropical convective rainfall. The recovery phase and the immediate post-OAE2 period were once more characterized by weaker chemical weathering and a stronger response to orbital forcing, typical for a monsoonal regime at the northern edge of the seasonal swing of the Intertropical Convergence Zone (ITCZ). Persistently high temperatures (O'Brien et al., 2017) in the recovery and post-OAE2 phase, as indicated by low $\delta^{18} \mathrm{O}$ in $\mathrm{SN}^{\circ} 4$, suggest that the equatorward shift of the monsoonal zone and southward expansion of the high-pressure desert belt occurred during a period of global warming. Changes in the weathering regime during the carbon isotope excursion may thus have been linked to major fluctuations in atmospheric $\mathrm{CO}_{2}$ associated with increased carbon burial and enhanced response to local insolation forcing in the late onset and peak phase of OAE2 (Fig. 5).

\subsection{Definitions and durations of OAE1a and OAE2}

The estimated durations of OAE1a and OAE2 depend on the definitions of the events (based either on the stratigraphic extent of organic-rich sediments or $\delta^{13} \mathrm{C}$ excursions) and vary substantially from minimum estimates of $45 \mathrm{kyr}$ for OAE $1 \mathrm{~b}$ to $>3 \mathrm{Myr}$ for OAE1a (Table 1). Whereas there is a broader consensus in defining the duration of OAE2 as the entire interval between the onset of the positive $\delta^{13} \mathrm{C}$ excursion and the end of the recovery phase, the definition of OAE1a is commonly restricted to the interval of organic-rich sedimentation (Selli Level). This interval encompasses the onset and peak of the $\delta^{13} \mathrm{C}$ excursion but does not include the plateau and recovery phase (e.g. Malinverno et al., 2010). At La Bédoule, these differences result in durations of $1.1 \mathrm{Myr}$ (onset and peak phases only) and $2.7 \mathrm{Myr}$ (including plateau and recovery phases), which is almost 4 times the duration of OAE2. The differences in the definition of OAE1a and OAE2 stem from the different stratigraphic relationship between black shale accumulation and $\delta^{13} \mathrm{C}$ excursion in most of the "classic" localities in central and northern Italy, Britain, and North Africa. At these locations, the highest accumulation rates of organic carbon occurred within the peak and plateau phase of the carbon isotope excursion during OAE2, whereas during OAE1a the duration of black shale deposition was much shorter than the $\delta^{13} \mathrm{C}$ excursion.

\subsubsection{OAE1a}

The restriction of the black shale facies (Selli Level) to the onset phase of the global carbon isotope curve in many classical OAE1a localities requires an additional carbon sink to account for the globally high $\delta^{13} \mathrm{C}$ values in segments $\mathrm{C} 6$ and C7 if we assume that the same mechanism of organic carbon burial is responsible for global positive $\delta^{13} \mathrm{C}$ excursions. However, the sedimentary record of black shales and ocean anoxia is patchy across OAE1a. Typical black shales with high TOC values corresponding to the Selli Level of OAE1a are not encountered in the stratigraphic succession of La Bédoule. Typical examples such as the Resolution Guyot record (Jenkyns, 1995) and the classical records from Cismon and Piobbico (Erba, 1992; Erba et al., 1999) are likely not fully representative of global organic matter accumulation across OAE1a. Preliminary TOC data from more complete sedimentary successions across OAE1a in southern Spain (Cau section and the recently drilled Cau core; Naafs et al., 2016; Ruiz-Ortiz et al., 2016) provide evidence for enhanced organic carbon accumulation during carbon isotope segment C7 (Naafs et al., 2016). These sections exhibit unusually high sedimentation rates and a carbon isotope record which matches that of La Bédoule (Naafs et al., 2016), underlining the completeness of both records. In the northern South Atlantic (e.g. DSDP Site 364 offshore Angola), an expanded sediment sequence showing evidence of cyclic episodes of intense anoxia-euxinia was deposited at neritic depths in a large, restricted basin (Behrooz et al., 2018; Kochhann et al., 2014), which may have contributed to organic carbon burial during C6 and C7. There is also evidence of black shale facies extending beyond isotope segment $\mathrm{C} 6$ in northeastern Tunisia (Elkhazri et al., 2013), albeit with TOC values in the upper Bedoulian black limestone facies (corresponding to segment C7) significantly lower $(<0.5 \%)$ than in the black limestones deposited within the $\mathrm{C} 4$ segment $(4.5 \%)$.

Other possible candidates for enhanced organic carbon burial during the plateau stage of the $\delta^{13} \mathrm{C}$ excursion are shallow marine to brackish water sediments in the high Arctic (i.e. Axel Heiberg Island, Canadian Arctic Archipelago), where organic-carbon-rich sedimentation (TOC $>5 \%$ ) persisted during most of OAE1a (Herrle et al., 2015). However, the most likely location for the burial of larger amounts of organic carbon during OAE1a is the central and east Pacific Ocean. Incompletely cored sequences on the Shatsky Rise indicate the deposition of organic-matter-rich sediments during OAE1a under dysoxic-anoxic conditions at ODP Sites 1207 and 1213 that possibly extended into the upper part of the $\delta^{13} \mathrm{C}$ excursion (Dumitrescu and Brassell, 2005, 2006; Dumitescu et al., 2006). Moreover, large areas of lower Cretaceous crust and sediments along the margins of the Pacific Ocean, which are likely candidates for organic-matter-rich 
sedimentation, have been subducted, leaving less than $15 \%$ of the lower Aptian ocean sea floor accessible today (Hay, 2007). Thus, we consider the record of global organic carbon burial documented by the positive $\delta^{13} \mathrm{C}$ excursion to be more representative for the duration of OAE1a than the stratigraphic extent of local black shales. However, this view strongly depends on the interpretation of globally elevated $\delta^{13} \mathrm{C}$ values as the result of enhanced organic carbon burial. We cannot fully exclude an influence of shallow marine and terrestrial carbonate cycles in maintaining elevated $\delta^{13} \mathrm{C}$ values in the marine dissolved inorganic carbon reservoir (Weissert et al., 1998). For example, an increase in the proportion of carbonate weathering, relative to organic carbon and silicate weathering, could have maintained long-lasting positive excursions in marine $\delta^{13} \mathrm{C}$ without substantially enhanced burial of organic carbon (Kump and Arthur, 1999).

Our estimated durations of OAE1a isotope stages agree with those of Malinverno et al. (2010) for the C6 to C8 stages (Table 2) but deviate from the reconstruction of Scott (2016). Minor differences with the estimates of Malinverno et al. (2010) are caused by differing definitions of boundaries between isotope stages in the Cismon core and the LB3-LB1 composite record as well as by different calculations of orbital periods. The plateau phase (C7) lasted for $1340 \mathrm{kyr}$ in the LB3-LB1 record, in agreement with estimates of $1590 \mathrm{kyr}$ by Malinverno et al. (2010) and $990 \mathrm{kyr}$ by Scott (2016). The duration of $315 \mathrm{kyr}$ for stage C6 agrees with the 349 kyr estimate by Malinverno et al. (2010) but substantially differs from the $110 \mathrm{kyr}$ proposed by Scott (2016). There are larger deviations from the estimates of Malinverno et al. (2010) and Scott (2016) for stages C5 and C4 in the LB3-LB1 record. Isotope stage C5 has a shorter duration of $280 \mathrm{kyr}$ compared to $510 \mathrm{kyr}$, estimated by Malinverno et al. (2010), but agrees with the $210 \mathrm{kyr}$ duration of Scott (2016). By contrast, the main increase in the positive carbon isotope excursion, corresponding to $\mathrm{C} 4$ (Menegatti et al., 1998), has a duration of $390 \mathrm{kyr}$ in LB3-LB1, which is $\sim 60 \%$ longer than the estimate of $239 \mathrm{kyr}$ by Malinverno et al. (2010) and $\sim 140 \%$ longer than the $160 \mathrm{kyr}$ duration of Scott (2016). The duration of C4 in LB3-LB1 is interpreted as a response to long eccentricity ( $405 \mathrm{kyr})$. Strong eccentricity control during the precursor phase (C3) and during the onset phase (C4) is supported by EHA and power spectra (Figs. 4, S3.1 and S3.2), suggesting that orbital eccentricity influenced the global carbon cycle and regional sedimentation. The largest differences are within the precursor phase (C3), with $440 \mathrm{kyr}$ in LB3-LB1 and $46.7 \mathrm{kyr}$ in the Cismon core reconstructed by Malinverno et al. (2010) as well as the $80 \mathrm{kyr}$ estimate of Scott (2016), which is probably caused by hiatuses in the Cismon APTICORE record. Malinverno et al. (2010) and Scott (2016) did not rule out the occurrence of smaller sedimentary gaps in the OAE1a sequence of the Cismon core, which are not long enough to compromise the complete biostratigraphic succession reconstructed by Erba et al. (1999).

\subsubsection{OAE2}

The negative carbon isotope excursion at the onset of OAE2 is absent from many classic OAE2 sections in Europe and the US Western Interior Basin due to the stratigraphic incompleteness of these records. The missing negative excursion is commonly associated with a short-term hiatus at the onset of the positive excursion, often expressed as a sharp lithological contact (the base of the Bonarelli horizon in some of the Umbrian Scaglia sections (Italy), Jenkyns et al., 2007, Batenburg et al., 2016; a sub-plenus erosion surface in the Eastbourne section (UK), Paul et al., 1999, Gale et al., 2005). However, negative spikes preceding the onset of the positive $\delta^{13} \mathrm{C}$ excursion were documented in high-resolution datasets, even in the relatively condensed Umbrian sections (e.g. Furlo section; Jenkyns et al., 2007) and in more expanded shelf sections at Wunstorf, northern Germany (Voigt et al., 2008), and Oued Mellegue, Tunisia (Nederbragt and Fiorentino, 1999). Records from expanded sections in Mexico (Elrick et al., 2009) and Japan (Nemoto and Hasegawa, 2011) also clearly exhibit the negative excursion. Recently, a high-resolution $\delta^{13} \mathrm{C}$ record from the South Pacific Ocean and a cyclostratigraphic age model based on magnetic susceptibility measurements indicated that the duration of the negative excursion was $\sim 50 \mathrm{kyr}$ ( $\mathrm{Li}$ et al., 2017b; Gangl et al., 2019) and allowed for the correlation of the onset of the negative isotope shift with the beginning of LIP activity at $\sim 94.44 \pm 0.14 \mathrm{Ma}$ (Du Vivier et al., 2015). These estimates (Table 3) for the precursor phase agree with our new durations of $75 \mathrm{kyr}$ for the last two prominent $\delta^{13} \mathrm{C}_{\text {org }}$ minima in Core $\mathrm{SN}^{\circ} 4$. The onset phase lasted for $68 \mathrm{kyr}$ in core $\mathrm{SN}^{\circ} 4$, broadly in agreement with $30 \pm 13 \mathrm{kyr}$ estimated by Gangl et al. (2019) for the Gongzha section (Tibet) and $110 \pm 25 \mathrm{kyr}$ for stage 3a in the Sawpit Gully section (New Zealand) of Li et al. (2017b). There is a larger discrepancy for the peak phase, with $86 \mathrm{kyr}$ reconstructed for the Tarfaya Basin and $170 \pm 25$ and $200 \pm 25 \mathrm{kyr}$ for the sections in Tibet and New Zealand, respectively, possibly caused by undetected short-term sedimentation rate changes connected to climatic changes during the Plenus Cold Event. Estimates for the duration of the plateau and recovery phase vary widely between the three localities, possibly arising from difficulties defining the inflection point at the beginning and end of the plateau phase. The plateau phase lasted for $204 \mathrm{kyr}$ in the Tarfaya Basin, $370 \pm 25 \mathrm{kyr}$ in Tibet and $660 \pm 25 \mathrm{kyr}$ in the Sawpit Gully section. The newly reconstructed duration of the recovery phase in the Tarfaya Basin is $435 \mathrm{kyr}$, contrasting with the much shorter durations of the Gongzha $(170 \pm 25 \mathrm{kyr})$ and Sawpit Gully ( $40 \pm 25 \mathrm{kyr})$ sections. The agreement in the cumulative length of the plateau and recovery phase underlines the difficulties in defining and reconstructing durations for the latest part of OAE2. 


\subsubsection{Amplitude of $\delta^{13} \mathrm{C}$ excursions}

The amplitude of carbon isotope excursions is generally higher for organic matter than for bulk carbonate (Jenkyns, 2010). This is the case for OAE2 in the Tarfaya Basin, where the amplitude is $\sim 4 \%$ o for organic $\delta^{13} \mathrm{C}$ and $\sim 2.5 \%$ ofor carbonate $\delta^{13} \mathrm{C}$ across the basin (Kuhnt et al., 1986, 1990, 2005, 2017; Kolonic et al., 2005; Tsikos et al., 2004). In the Tarfaya Basin, the high organic content is of marine origin, and changes in $\delta^{13} \mathrm{C}$ values thus mainly reflect global reservoir changes at intermediate values of local productivity (Van Bentum et al., 2012). However, marked regional differences in the amplitude of the organic and bulk inorganic $\delta^{13} \mathrm{C}$ excursions were also reported for OAE2 (Van Bentum et al., 2012; Wendler, 2013; Kuhnt et al., 2017). Possible causes include local differences in the $\delta^{13} \mathrm{C}$ of dissolved inorganic carbon dependent on local productivity, oxygenation and diagenesis (Kuypers et al., 1999; Jenkyns, 2010; Van Bentum et al., 2012; Kuhnt et al., 2017). Similar differences in the amplitude of $\delta^{13} \mathrm{C}$ excursions are recorded for OAE1a: the highest amplitudes reach or slightly exceed $4 \%$ in both organic carbon and carbonate from the western Tethys margin (e.g. Menagatti et al., 1998), whereas at deepwater localities with distinct black shale deposition of the Selli event the amplitude remains lower ( $\sim 2.5 \%$; Malinverno et al., 2010).

A long-term increase in $\delta^{13} \mathrm{C}$ over the Cretaceous and early Cenozoic was reported by Katz et al. (2005) and attributed to the evolution of large-celled phytoplankton and increased organic carbon burial efficiency in expanding depositional spaces (e.g. shallow shelves around the Atlantic) created during the rifting phase of the current Wilson cycle (Wilson, 1966; Worsley et al., 1986). Continuous removal of isotopically light organic carbon by deposition in shallow seas depleted the global carbon reservoir. The OAE1a and OAE2 records show differences in the background levels between the preceding intervals and after the terminations of both events, with $0.8 \%$ in $\delta^{13} \mathrm{C}_{\text {carb }}$ for OAE1a and $0.3 \%$ o in $\delta^{13} \mathrm{C}_{\text {org }}$ for OAE2. An overall increase over OAE2 is also reconstructed for deposits of the English chalk (Jarvis et al., 2006). We assume that the long-term increase observed by Katz et al. (2005) was stepwise and to a large degree influenced by Cretaceous OAEs. The large-scale isotopic depletion of the global carbon reservoir accompanying these major disturbances of the global carbon cycle was not entirely compensated for during the recovery phase and in the multimillion-year interval following these events, inducing a long-term increase in $\delta^{13} \mathrm{C}$ during the Cretaceous.

\subsection{Impact of orbital forcing on the evolution of OAE1a and OAE2}

The orbital configuration favouring enhanced marine biological productivity in low latitudes may have been different for OAE1a and OAE2. Recent studies (e.g. Batenburg et al., 2016; Kuhnt et al., 2017) tuned the onset of OAE2 to a $405 \mathrm{kyr}$ eccentricity maximum that succeeded an extended period of low seasonality, caused by a $2.4 \mathrm{Myr}$ eccentricity minimum, which would be associated with stronger obliquity forcing during the precursor phase. The much shorter onset phase of OAE2 suggests a faster and stronger response of the ocean-climate system to the carbon cycle perturbation, either related to a shorter and more intense initial carbon dioxide release or to a different orbital configuration such as higheramplitude eccentricity cycles. Additionally, higher rates of sea level rise would have promoted enhanced organic carbon burial in shallow shelf seas. These extensive dysoxic to anoxic shelf seas would have favoured the fast recycling of limiting nutrients, thereby enhancing primary production and further boosting organic carbon burial. Eccentricity control on both sea level and organic carbon burial is also suggested by the $\sim 90$ and $\sim 600 \mathrm{kyr}$ durations of the peak phases of OAE2 and OAE1a (maximum organic carbon deposition and the highest $\delta^{13} \mathrm{C}$ values) (Figs. 4 and 5).

By contrast, a strong obliquity imprint is detected during the plateau phases (Figs. 4 and 5). A period of highamplitude obliquity forcing would have steepened the latitudinal temperature gradient and intensified atmospheric circulation (Batenburg et al., 2016; Kuhnt et al., 2017), thus helping to maintain elevated biological productivity in the tropical oceans. The obliquity-forced intensification of monsoonal systems may have resulted in periods of enhanced tropical weathering associated with enhanced nutrient supply to the ocean and wind-driven equatorial upwelling, which promoted carbon sequestration during the plateau and recovery phases. However, the recycling of essential nutrients from buried sediments or release from new sources (e.g. flood basalts of LIPs) would have been necessary to maintain this new equilibrium state over extended periods of time. The plateau stage lasted 7 times longer during OAE1a than during OAE2, which excludes orbital forcing as a primary control on its duration. This is also supported by differences in the response to orbital forcing at the end of the plateau phases: a precession and obliquity imprint during OAE1a contrast with a persistent obliquity signal during OAE2.

In addition to precessional variability, changes in orbital obliquity were a critical forcing factor of climate oscillations during the recovery phase of both OAEs. Obliquity determines the summer intertropical insolation gradient, which was recently suggested as an important driver of changes in tropical and subtropical hydrology and sedimentation patterns (Bosmans et al., 2015). An increased insolation gradient between the tropical summer and winter hemisphere during high obliquity leads to intensified atmospheric circulation within the Hadley cell, resulting in stronger crossequatorial winds and intensified moisture transfer into the summer hemisphere. Continental climate proxy data and models suggest a contraction of the Hadley cell and a latitudinal shift of the subtropical high-pressure belt towards the Equator during mid-Cretaceous super-greenhouse conditions (Hasegawa et al., 2012; Hay and Flögel, 2012). This 
climate scenario would have placed the hinterland of the Tarfaya Basin in the dry, hot subtropical desert climate zone during OAE2, whereas the La Bédoule area was likely influenced by the humid zone of the Northern Hemisphere westerlies during OAE1a. An increase in cross-equatorial winds and intensified rainfall at obliquity maxima would thus have affected the Tarfaya Basin by increasing upper ocean mixing and upwelling and the La Bédoule area by increased rainfall due to intensified westerlies.

Periods of high-amplitude $41 \mathrm{kyr}$ obliquity variations last $\sim 400-800 \mathrm{kyr}$ and are separated by nodes of weak obliquity forcing with a duration of $\sim 200-400 \mathrm{kyr}$ (Fig. S5.1, Laskar et al., 2004). During the recovery phase of OAEs, obliquityforced low-latitude climate oscillations may have led to periods of enhanced equatorial upwelling, which would have promoted carbon sequestration and, over several hundred thousand years, depleted the ocean's nutrient pool. A period of low variability in orbital obliquity (obliquity node), commonly associated with global cooling episodes in Cenozoic climate records (e.g. Pälike et al., 2006), may have ultimately terminated OAE1a and 2.

\subsection{Role of phosphorus recycling in maintaining high productivity during OAEs}

Phosphorus is the primary limiting nutrient controlling marine biological productivity on longer (geological) timescales (e.g. Holland, 1978; Broecker and Peng, 1982; Smith, 1984; Codispoti, 1989), with the potential to control the occurrence of high-productivity events (e.g. Föllmi, 1996; Handoh and Lenton, 2003). In contrast to nitrate, which can be synthesized from atmospheric nitrogen primarily by cyanobacterial $\mathrm{N}_{2}$ fixation under anoxic conditions (e.g. Rigby and Batts, 1986; Rau et al., 1987; Kuypers et al., 2004), the phosphorus supply to the ocean is restricted by riverine terrestrial input (Ruttenberg, 2003). This constitutes a limiting factor for increased marine primary productivity. Thus, alternative nutrient sources such as enhanced terrestrial input or the recycling of marine sediments were necessary to sustain high primary productivity over the extended durations of Cretaceous OAEs (e.g. Nedebragt et al., 2004).

$\mathrm{C}_{\text {org }} / \mathrm{P}_{\text {react }}$ and $\mathrm{N}_{\text {total }} / \mathrm{P}_{\text {react }}$ close to or above the Redfield ratio were measured within the MCE and OAE2 intervals, suggesting the preservation of the initial atomic ratio of primary production, possibly even enhanced by a change in the phytoplankton community (Geider and La Roche, 2002) or depletion in $\mathrm{P}_{\text {react }}$. Unusually high phosphorus values in the intervals preceding the MCE and during the onset of OAE2 were likely caused by starved sedimentation, which may be due to the formation of hard grounds and condensed sections at sea level high stands or winnowing of fine-grained sediment by intensified bottom currents.

Regional changes in redox conditions towards anoxic or euxinic conditions in the lower water column would have inhibited the fixation of remobilized phosphorus in authigenic
$\mathrm{CaP}$, thus allowing the leakage of phosphorus into the water column and resulting in increased sedimentary $\mathrm{C}: \mathrm{P}$ and $\mathrm{N}: \mathrm{P}$. Intensification of oxygen depletion during the plateau phase of OAE2 is associated with increasing $\mathrm{C}_{\text {org }} / \mathrm{P}_{\text {react }}$ and $\mathrm{N}_{\text {total }} / \mathrm{P}_{\text {react }}$ due to reduced diagenetic phosphorus precipitation, permitting phosphorus leakage from the sediment into the water column. However, phosphorus accumulation rates started to decline earlier during the precursor phase of OAE2. A trend toward more reducing conditions during the plateau and recovery phase of OAE2 was also suggested by Kolonic et al. (2005) based on high accumulation rates of redox-sensitive elements. A similar sequence of events was reconstructed by Stein et al. (2011) for OAE1a in deposits from the Gorgo a Cerbara section (Umbria-Marche basin) in central Italy (Sect. S11). Phosphorus accumulation and $\mathrm{C}_{\text {org }} / \mathrm{P}_{\text {total }}$ increased during the precursor phase (C3 of Menegatti et al., 1998) and decreased during the onset phase (C4 of Menegatti et al., 1998), suggesting enhanced phosphorus recycling from the sediments, as for OAE2 in Core $\mathrm{SN}^{\circ} 4$ (Fig. 8 and Sect. S11). Stein et al. (2011) also reported a minor increase in $\mathrm{C}_{\mathrm{org}} / \mathrm{P}_{\text {total }}$ at the base of the peak phase $(\mathrm{C} 5+\mathrm{C} 6)$ and persistently high $\mathrm{C}_{\text {org }} / \mathrm{P}_{\text {total }}$ during the late peak phase (C5+C6), as for OAE2 in Core $\mathrm{SN}^{\circ} 4$.

An earlier study by Poulton et al. (2015), focusing on $\mathrm{Fe}$ speciation proxies during the onset, peak and early plateau phase of OAE2 in nearby drill core S57, found cyclic variations between euxinic and ferruginous conditions. The stratigraphically extended interval (from the MCE to early Turonian) investigated at lower resolution by Scholz et al. (2019) is characterized by a high proportion of unpyritized reactive $\mathrm{Fe}$ in the total Fe pool. The results of this study are consistent with a proxy signature that is indicative of anoxic and non-sulfidic, so-called ferruginous, water column conditions throughout the studied interval (Poulton and Canfield, 2011). However, Scholz et al. (2019) argued that dissolved Fe (and hydrogen sulfide) concentrations in the water column of the Tarfaya system were unlikely higher than those observed in modern upwelling zones (e.g. Peru margin) on account of the low terrigenous sedimentation rates and tropical weathering on the adjacent continent. Previous studies proposed that phosphorus burial might be enhanced under ferruginous conditions, implying a negative feedback for the oceanic phosphorus pool and primary production (e.g. März et al., 2008). However, Scholz et al. (2019) did not observe a close relationship between $\mathrm{Fe}$ and $\mathrm{P}$ burial despite a ferruginous signature in the sediments, which supports the notion that dissolved Fe concentrations and rates of Fe oxide precipitation in the Tarfaya Basin were moderate and overall similar to modern upwelling systems (Wallmann et al., 2019).

The impact of oxygen depletion on the release of phosphorus into the water column was shown by recent studies on modern OMZs (e.g. Noffke et al., 2012; Schollar-Lomnitz et al., 2019) with implications for increased primary productivity through feedback mechanisms. Phosphorus recycling from the sediments may have sustained high primary pro- 
ductivity over extended periods of time, thus contributing to the long duration of OAE1a and OAE2. Phosphorus remobilization under anoxic conditions from vast areas of flooded shelf sediments facilitated high organic carbon burial rates during the onset, peak and plateau phases of the three anoxic events and may have acted as a positive feedback process, enhancing carbon burial and the removal of light carbon isotopes from the marine dissolved inorganic carbon reservoir and resulting in positive carbon isotope excursions.

\section{Conclusions}

New high-resolution stable isotope and XRF scanner data were integrated with published records from Cores LB1 and LB3 in the South Provence Basin (Lorenzen et al., 2013; Moullade et al., 2015) and from Core $\mathrm{SN}^{\circ} 4$ in the Tarfaya Basin (Kuhnt et al., 2017; Beil et al., 2018) to contrast the temporal evolution of two of the most significant oceanic anoxic events: OAE1a and OAE2. The structure of the marine $\delta^{13} \mathrm{C}$ records suggests a similar evolution of the carbon cycle during both OAEs, although the duration of the individual phases differed substantially. Both OAEs exhibit negative excursions (precursor phase), with a duration of $\sim 430 \mathrm{kyr}$ (OAE1a) and $\sim 130 \mathrm{kyr}$ (OAE2), immediately preceding the onset of the positive carbon isotope excursion. The onset phases, lasting $\sim 390 \mathrm{kyr}$ for OAE1a and $\sim 70 \mathrm{kyr}$ for OAE2, were characterized by intervals of rapid $\delta^{13} \mathrm{C}$ increase separated by small plateaus with slower $\delta^{13} \mathrm{C}$ change. Prominent cooling events recorded as $\delta^{18} \mathrm{O}$ increases started during the latest onset phase and extended into the peak phase (Plenus Cold Event during OAE2), which lasted $\sim 600 \mathrm{kyr}$ during OAE1a and only $\sim 90 \mathrm{kyr}$ during OAE2. The plateau phase extended over $\sim 1340 \mathrm{kyr}$ for OAE1a but lasted only $\sim 200 \mathrm{kyr}$ for OAE2. However, the durations of the recovery phases were similar with $\sim 380 \mathrm{kyr}$ (OAE1a) and $\sim 440 \mathrm{kyr}$ (OAE2). The different durations of the precursor and plateau phases of OAE1a and OAE2 may have been linked to the magnitude and duration of the triggering volcanic exhalations. In addition, different orbital configurations may have influenced long-term marine organic carbon burial on a global scale.

Phosphorus speciation data from Core $\mathrm{SN}^{\circ} 4$ in the Tarfaya Basin provide new insights into the dynamics of this essential nutrient during the MCE and OAE2. Phosphorus speciation shows a predominance of Ca-bound phosphorus surpassing concentrations of $\mathrm{Al} / \mathrm{Fe}-$ bound $\mathrm{P}$ by 1 to 2 orders of magnitude. Phosphorus bound to $\mathrm{Al}$ and Fe oxyhydroxides is elevated during the early Cenomanian (305$273 \mathrm{~m}$ ) in Core $\mathrm{SN}^{\circ} 4$, reflecting sedimentation in a shallower environment or the less intensive redox-induced early diagenetic cycling of iron oxyhydroxides. Elevated ratios of $\mathrm{C}_{\text {org }} / \mathrm{P}_{\text {react }}$ and $\mathrm{N}_{\text {total }} / \mathrm{P}_{\text {react }}$ during the MCE and OAE2 indicate a change in the water column towards more reducing conditions. Oxygen-free bottom water permitted the leakage of dissolved phosphorus from the sedimentary column and increased the ratios of $\mathrm{C}_{\text {org }}$ and $\mathrm{N}_{\text {total }}$ to $\mathrm{P}_{\text {react }}$ within the sediments. This change is apparently synchronous with enhanced organic carbon burial in the Tarfaya Basin. The delayed increase in $\mathrm{C}_{\text {org }} / \mathrm{P}_{\text {react }}$ and $\mathrm{N}_{\text {total }} / \mathrm{P}_{\text {react }}$ with respect to the $\delta^{13} \mathrm{C}_{\text {org }}$ increase suggests that the Cenomanian OAEs were not initiated by shelfal phosphorus remobilization. However, the coincidence of maximum organic carbon burial and the highest $\mathrm{C}_{\text {org }} / \mathrm{P}_{\text {react }}$ and $\mathrm{N}_{\text {total }} / \mathrm{P}_{\text {react }}$ underlines the significance of phosphorus leakage from sediments for maintaining the high organic carbon burial rates necessary to sustain globally recognized $\delta^{13} \mathrm{C}$ shifts during OAEs over extended time periods.

Data availability. Newly acquired data from this study are available at https://doi.org/10.1594/PANGAEA.912375 (Beil et al., 2020).

Supplement. The supplement related to this article is available online at: https://doi.org/10.5194/cp-16-757-2020-supplement.

Author contributions. SB, WK and AH designed the study and wrote the paper. WK, $\mathrm{AH}$ and MA planned and supervised the drilling of Cores $\mathrm{LB} 1, \mathrm{LB} 3$ and $\mathrm{SN}^{\circ} 4$. Data for this study were acquired by SB, MA, JL, JO, FS, KW, AH and WK. Time series analysis was performed by SB. EHC facilitated fieldwork and drilling. All authors read and provided comments on the paper.

Competing interests. The authors declare that they have no conflict of interest.

Special issue statement. This article is part of the special issue "Ocean deoxygenation: drivers and consequences - past, present and future (BG/CP/OS inter-journal SI)". It is a result of the International Conference on Ocean Deoxygenation , Kiel, Germany, 3-7 September 2018.

Acknowledgements. We would like to thank Nils Andersen (Leibniz Laboratory for Radiometric Dating and Stable Isotope Research, Kiel) and Michael Joachimski (GeoZentrum Nordbayern, Friedrich-Alexander University of Erlangen-Nürnberg, Erlangen) for stable isotope measurements, Dieter Garbe Schönberg and Samuel Müller (Institute of Geosciences (Institute of Geosciences, Kiel University) for X-ray fluorescence scanning advice, and Anke Bleyer, Bettina Domeyer and Regina Surberg (GEOMAR, Kiel) for laboratory assistance.. We would like to gratefully acknowledge Hugh Jenkyns, Christian März and Matthew Clarkson for insightful reviews that significantly improved the paper. 
Financial support. This project was supported by the German Research Foundation (DFG) through subproject A7 of the Collaborative Research Center (SFB) 754 (Climate-Biogeochemistry Interactions in the Tropical Oceans) and the Emmy Noether Research Group ICONOX (Iron Cycling in Continental Margin Sediments and the Nutrient and Oxygen Balance of the Ocean). Both projects are funded by the DFG: A7 through the SFB754 and ICONOX through the Emmy Noether Research Group.

Review statement. This paper was edited by Babette Hoogakker and reviewed by Matthew Clarkson and Hugh Jenkyns.

\section{References}

Anderson, L. D., Delaney, M. L., and Faul, K. L.: Carbon to phosphorus ratios in sediments: Implications for nutrient cycling, Global Biogeochem. Cy., 15, 65-79, https://doi.org/10.1029/2000GB001270, 2001.

Ando, A., Huber, B. T., MacLeod, K. G., Ohta, T., and Khim, B. K.: Blake Nose stable isotopic evidence against the midCenomanian glaciation hypothesis, Geology, 37, 451-454, https://doi.org/10.1130/G25580A.1, 2009.

Arning, E. T., Birgel, D., Brunner, B., and Peckmann, J.: Bacterial formation of phosphatic laminites off Peru, Geobiology, 7, 295307, https://doi.org/10.1111/j.1472-4669.2009.00197.x, 2009a.

Arning, E. T., Lückge, A., Breuer, L. C., Gussone, N., Birgel, D., and Peckmann, J.: Genesis of phosphorite crusts off Peru, Mar. Geol., 262, 68-81, https://doi.org/10.1016/j.margeo.2009.03.006, 2009b.

Arthur, M. A., Dean, W. E., and Schlanger, S. O.: Variations in the Global Carbon Cycle During the Cretaceous Related to Climate, Volcanism, and Changes in Atmospheric $\mathrm{CO}_{2}$, in: The Carbon Cycle and Atmospheric $\mathrm{CO}_{2}$ : Natural Variations Archean to Present, edited by: Sundquist, E. and Broecker, W., American Geophysical Union, Washington D.C., USA, 32, 504-529, https://doi.org/10.1029/GM032p0504, 1985.

Arthur, M. A., Dean, W. E., and Pratt, L. M.: Geochemical and climatic effects of increased marine organic carbon burial at the Cenomanian/Turonian boundary, Nature, 335, 714-717, https://doi.org/10.1038/335714a0, 1988.

Batenburg, S. J., De Vleeschouwer, D., Sprovieri, M., Hilgen, F. J., Gale, A. S., Singer, B. S., Koeberl, C., Coccioni, R., Claeys, P., and Montanari, A.: Orbital control on the timing of oceanic anoxia in the Late Cretaceous, Clim. Past, 12, 19952009, https://doi.org/10.5194/cp-12-1995-2016, 2016.

Behrooz, L., Naafs, B. D. A., Dickson, A. J., Love, G. D., Batenburg, S. J., and Pancost, R. D.: Astronomically driven variations in depositional environments in the South Atlantic during the Early Cretaceous, Paleoceanogr. Paleocl., 33, 894-912, https://doi.org/10.1029/2018PA003338, 2018.

Beil, S., Kuhnt, W., Holbourn, A. E., Aquit, M., Flögel, S., Chellai, E. H., and Jabour, H.: New insights into Cenomanian paleoceanography and climate evolution from the Tarfaya Basin, southern Morocco, Cretaceous Res., 84, 451-473, https://doi.org/10.1016/j.cretres.2017.11.006, 2018.

Beil, S., Kuhnt, W., Holbourn, A., Scholz, F., Wallmann, K., Lorenzen, J., Aquit, M., and Chellai, E. H.: Creta- ceous Oceanic Anoxic Events prolonged by phosphorus cycle feedbacks, data from SN4 and La Bedoule, PANGAEA, https://doi.org/10.1594/PANGAEA.912375, 2020.

Berger, W. H. and Vincent, E.: Deep-sea carbonates: reading the carbon-isotope signal, Geol. Rundsch., 75, 249-269, https://doi.org/10.1007/BF01770192, 1986.

Bornemann, A., Erbacher, J., Heldt, M., Kollaske, T., Wilmsen, M., Lübke, N., Huck, S., Vollmar, N. M., and Wonik, T.: The Albian-Cenomanian transition and Oceanic Anoxic Event 1d an example from the boreal realm, Sedimentology, 64, 44-65, https://doi.org/10.1111/sed.12347, 2017.

Bosmans, J. H. C., Hilgen, F. J., Tuenter, E., and Lourens, L. J.: Obliquity forcing of low-latitude climate, Clim. Past, 11, 13351346, https://doi.org/10.5194/cp-11-1335-2015, 2015.

Bottini, C., Erba, E., Tiraboschi, D., Jenkyns, H. C., Schouten, S., and Sinninghe Damsté, J. S.: Climate variability and ocean fertility during the Aptian Stage, Clim. Past, 11, 383-402, https://doi.org/10.5194/cp-11-383-2015, 2015.

Broecker, W. S. and Peng, T.-H.: Tracers in the Sea, Eldigio Press, Palisades, New York, USA, 1982.

Calvert, S. E. and Pedersen, T. F.: Chapter fourteen elemental proxies for palaeoclimatic and palaeoceanographic variability in marine sediments: interpretation and application, in: Developments in Marine Geology, edited by: Hillaire-Marcel, C. and De Vernal, A., Elsevier, 1, 567-644, https://doi.org/10.1016/S15725480(07)01019-6, 2007.

Charbonnier, G., Boulila, S., Spangenberg, J. E., Adatte, T., Föllmi, K. B., and Laskar, J.: Obliquity pacing of the hydrological cycle during the Oceanic Anoxic Event 2, Earth Planet. Sc. Lett., 499, 266-277, https://doi.org/10.1016/j.epsl.2018.07.029, 2018.

Coccioni, R. and Galeotti, S.: The mid-Cenomanian Event: prelude to OAE 2, Palaeogeogr. Palaeocl., 190, 427-440, https://doi.org/10.1016/S0031-0182(02)00617-X, 2003.

Codispoti, L. A.: Phosphorus vs. nitrogen limitation of new and export production, in: Productivity of the Ocean: Present and Past, edited by: Berger, W. H., Smetacek, V. S., and Wefer, G., Wiley, New York, USA, 377-394, 1989.

Cors, J., Heimhofer, U., Adatte, T., Hochuli, P. A., Huck, S., and Bover-Arnal, T.: Climatic evolution across oceanic anoxic event 1a derived from terrestrial palynology and clay minerals (Maestrat Basin, Spain), Geol. Mag., 152, 632-647, https://doi.org/10.1017/S0016756814000557, 2015.

Cosmidis, J., Benzerara, K., Menguy, N., and Arning, E.: Microscopy evidence of bacterial microfossils in phosphorite crusts of the Peruvian shelf: Implications for phosphogenesis mechanisms, Chem. Geol., 359, 10-22, https://doi.org/10.1016/j.chemgeo.2013.09.009, 2013.

Danzelle, J., Riquier, L., Baudin, F., Thomazo, C., and Pucéat, E.: Oscillating redox conditions in the Vocontian Basin (SE France) during Oceanic Anoxic Event 2 (OAE 2), Chem. Geol., 493, 136-152, https://doi.org/10.1016/j.chemgeo.2018.05.039, 2018.

Delaney, M. L.: Phosphorus accumulation in marine sediments and the oceanic phosphorus cycle, Global Biogeochem. Cy., 12, 563572, https://doi.org/10.1029/98GB02263, 1998.

Dickens, G. R., O’Neil, J. R., Rea, D. K., and Owen, R. M.: Dissociation of oceanic methane hydrate as a cause of the carbon isotope excursion at the end of the Paleocene, Paleoceanography, 10, 965-971, https://doi.org/10.1029/95PA02087, 1995. 
Dumitrescu, M. and Brassell, S. C.: Biogeochemical assessment of sources of organic matter and paleoproductivity during the early Aptian Oceanic Anoxic Event at Shatsky Rise, ODP Leg 198, Org. Geochem., 36, 1002-1022, https://doi.org/10.1016/j.orggeochem.2005.03.001, 2005.

Dumitrescu, M. and Brassell, S. C.: Compositional and isotopic characteristics of organic matter for the early Aptian Oceanic Anoxic Event at Shatsky Rise, ODP Leg 198, Palaeogeogr. Palaeocl., 235, 168-191, https://doi.org/10.1016/j.palaeo.2005.09.028, 2006.

Dumitrescu, M., Brassell, S. C., Schouten, S., Hopmans, E. C., and Sinninghe Damsté, J. S.: Instability in tropical Pacific seasurface temperatures during the early Aptian, Geology, 34, 833836, https://doi.org/10.1130/G22882.1, 2006.

Du Vivier, A. D., Selby, D., Sageman, B. B., Jarvis, I., Gröcke, D. R., and Voigt, S.: Marine ${ }^{187} \mathrm{Os} /{ }^{188} \mathrm{Os}$ isotope stratigraphy reveals the interaction of volcanism and ocean circulation during Oceanic Anoxic Event 2, Earth Planet. Sc. Lett., 389, 23-33, https://doi.org/10.1016/j.eps1.2013.12.024, 2014.

Du Vivier, A. D. C., Selby, D., Condon, D. J., Takashima, R., and Nishi, H.: Pacific ${ }^{187} \mathrm{Os} /{ }^{188} \mathrm{Os}$ isotope chemistry and $\mathrm{U}-\mathrm{Pb}$ geochronology: Synchroneity of global Os isotope change across OAE 2, Earth Planet. Sc. Lett., 428, 204-216, https://doi.org/10.1016/j.epsl.2015.07.020, 2015.

Eicher, D. L. and Worstell, P.: Cenomanian and Turonian foraminifera from the great plains, United States, Micropaleontology, 16, 269-324, https://doi.org/10.2307/1485079, 1970.

El Albani, A., Kuhnt, W., Luderer, F., Herbin, J. P., and Caron, M.: Palaeoenvironmental evolution of the Late Cretaceous sequence in the Tarfaya Basin (southwest of Morocco), Geol. Soc. (London) Spec. Publ., 153, 223-240, https://doi.org/10.1144/GSL.SP.1999.153.01.14, 1999.

Eldrett, J. S., Ma, C., Bergman, S. C., Lutz, B., Gregory, F. J., Dodsworth, P., Phipps, M., Hardas, P., Minisini, D., Ozkan, A., Ramezani, J., Bowing, S. A., Kamo, S. L., Ferguson, K., Macaulay, C., and Kelly, A. E.: An astronomically calibrated stratigraphy of the Cenomanian, Turonian and earliest Coniacian from the Cretaceous Western Interior Seaway, USA: Implications for global chronostratigraphy, Cretaceous Res., 56, 316344, https://doi.org/10.1016/j.cretres.2015.04.010, 2015.

Elkhazri, A., Abdallah, H., Razgallah, S., Moullade, M., and Kuhnt, W.: Carbon-isotope and microfaunal stratigraphy bounding the Lower Aptian Oceanic Anoxic Event 1a in northeastern Tunisia, Cretaceous Res., 39, 133-148, https://doi.org/10.1016/j.cretres.2012.05.011, 2013.

Elrick, M., Molina-Garza, R., Duncan, R., and Snow, L.: Cisotope stratigraphy and paleoenvironmental changes across OAE2 (mid-Cretaceous) from shallow-water platform carbonates of southern Mexico, Earth Planet. Sc. Lett., 277, 295-306, https://doi.org/10.1016/j.epsl.2008.10.020, 2009.

Erba, E.: Calcareous nannofossil distribution in pelagic rhythmic sediments (Aptian-Albian Piobbico core, central Italy), Riv. Ital. Paleontol. S, 97, 455-484, https://doi.org/10.13130/20394942/8959, 1992

Erba, E.: Calcareous nannofossils and Mesozoic oceanic anoxic events, Mar. Micropaleontol., 52, 85-106, https://doi.org/10.1016/j.marmicro.2004.04.007, 2004.

Erba, E., Channell, J. E., Claps, M., Jones, C., Larson, R., Opdyke, B., Premoli Silva, I., Riva, A., Salvini, G., and Torricelli, S.:
Integrated stratigraphy of the Cismon Apticore (southern Alps, Italy); a "reference section" for the Barremian-Aptian interval at low latitudes, J. Foramin. Res., 29, 371-391, 1999.

Erbacher, J., Huber, B. T., Norris, R. D., and Markey, M.: Increased thermohaline stratification as a possible cause for an ocean anoxic event in the Cretaceous period, Nature, 409, 325327, https://doi.org/10.1038/35053041, 2001.

Filippelli, G. M.: The global phosphorus cycle: past, present, and future, Elements, 4, 89-95, https://doi.org/10.2113/GSELEMENTS.4.2.89, 2008.

Flögel, S., Kuhnt, W., and Moullade, M.: Drilling of Early Cretaceous Oceanic Anoxic Event 1a in Southern France, Sci. Dril., 9, 20-22, https://doi.org/10.2204/iodp.sd.9.03.2010, 2010.

Föllmi, K. B.: The phosphorus cycle, phosphogenesis and marine phosphate-rich deposits, Earth-Sci. Rev., 40, 55-124, https://doi.org/10.1016/0012-8252(95)00049-6, 1996.

Föllmi, K. B.: Early Cretaceous life, climate and anoxia, Cretaceous Res., 35, 230-257, https://doi.org/10.1016/j.cretres.2011.12.005, 2012.

Forster, A., Schouten, S., Moriya, K., Wilson, P. A., and Sinninghe Damsté, J. S.: Tropical warming and intermittent cooling during the Cenomanian/Turonian oceanic anoxic event 2: Sea surface temperature records from the equatorial Atlantic, Paleoceanography, 22, PA1219, https://doi.org/10.1029/2006PA001349, 2007.

Friedrich, O., Erbacher, J., and Mutterlose, J.: Paleoenvironmental changes across the Cenomanian/Turonian boundary event (oceanic anoxic event 2) as indicated by benthic foraminifera from the Demerara Rise (ODP Leg 207), Rev. Micropaléontol., 49, 121-139, https://doi.org/10.1016/j.revmic.2006.04.003, 2006.

Gale, A. S.: A Milankovitch scale for Cenomanian time, Terra Nova, 1, 420-425, 1989.

Gale, A. S. and Christensen, W. K.: Occurrence of the belemnite Actinocamax plenus in the Cenomanian of SE France and its significance, B. Geol. Soc. Denmark, 43, 68-77, 1996.

Gale, A. S., Hardenbol, J., Hathway, B., Kennedy, W. J., Young, J. R., and Phansalkar, V.: Global correlation of Cenomanian (Upper Cretaceous) sequences: Evidence for Milankovitch control on sea level, Geology, 30, 291-294, https://doi.org/10.1130/00917613(2002)030<0291:GCOCUC>2.0.CO;2, 2002.

Gale, A. S., Kennedy, W. J., Voigt, S., and Walaszczyk, I.: Stratigraphy of the Upper Cenomanian-Lower Turonian Chalk succession at Eastbourne, Sussex, UK: ammonites, inoceramid bivalves and stable carbon isotopes, Cretaceous Res., 26, 460-487, https://doi.org/10.1016/j.cretres.2005.01.006, 2005.

Gambacorta, G., Malinverno, A., and Erba, E.: Orbital forcing of carbonate versus siliceous productivity in the late Albianlate Cenomanian (Umbria-Marche Basin, central Italy), Newsl Stratigr., 52, 197-220, https://doi.org/10.1127/nos/2018/0456, 2019.

Gangl, S. K., Moy, C. M., Stirling, C. H., Jenkyns, H. C., Crampton, J. S., Clarkson, M. O., Ohneiser, C., and Porcellid, D.: Highresolution records of Oceanic Anoxic Event 2: Insights into the timing, duration and extent of environmental perturbations from the palaeo-South Pacific Ocean, Earth Planet. Sc. Lett., 518, 172 182, https://doi.org/10.1016/j.eps1.2019.04.028, 2019.

Geider, R. and La Roche, J.: Redfield revisited: variability of C:N:P in marine microalgae and its biochemical basis, Eur. J. Phycol., 37, 1-17, https://doi.org/10.1017/S0967026201003456, 2002. 
Goldhammer, T., Brüchert, V., Ferdelman, T. G., and Zabel, M.: Microbial sequestration of phosphorus in anoxic upwelling sediments, Nat. Geosci., 3, 557-561, https://doi.org/10.1038/ngeo913, 2010.

Golterman, H. L.: Phosphate release from anoxic sediments or “What did Mortimer really write?", Hydrobiologia, 450, 99-106, https://doi.org/10.1023/A:1017559903404, 2001.

Govin, A., Holzwarth, U., Heslop, D., Ford Keeling, L., Zabel, M., Mulitza, S., Collins, J. A., and Chiessi, C. M.: Distribution of major elements in Atlantic surface sediments (36 $\mathrm{N}-49 \mathrm{~S}$ ): Imprint of terrigenous input and continental weathering, Geochem. Geophy. Geosy., 13, Q01013, https://doi.org/10.1029/2011GC003785, 2012.

Handoh, I. C. and Lenton, T. M.: Periodic mid-Cretaceous oceanic anoxic events linked by oscillations of the phosphorus and oxygen biogeochemical cycles, Global Biogeochem. Cy., 17, 1092, https://doi.org/10.1029/2003GB002039, 2003.

Hasegawa, H., Tada, R., Jiang, X., Suganuma, Y., Imsamut, S., Charusiri, P., Ichinnorov, N., and Khand, Y.: Drastic shrinking of the Hadley circulation during the mid-Cretaceous Supergreenhouse, Clim. Past, 8, 1323-1337, https://doi.org/10.5194/cp-81323-2012, 2012.

Hay, W. W.: Why Cretaceous paleoclimatology remains a mystery, GSA Denver Annual Meeting 2007, 28-31 October 2007, Denver, CO, 2007.

Hay, W. W. and Floegel, S.: New thoughts about the Cretaceous climate and oceans, Earth-Sci. Rev., 115, 262-272, https://doi.org/10.1016/j.earscirev.2012.09.008, 2012.

Herrle, J. O., Schröder-Adams, C. J., Davis, W., Pugh, A. T., Galloway, J. M., and Fath, J.: Mid-Cretaceous High Arctic stratigraphy, climate, and Oceanic Anoxic Events, Geology, 43, 403-406, https://doi.org/10.1130/G36439.1, 2015.

Hochuli, P. A., Menegatti, A. P., Weissert, H., Riva, A., Erba, E., and Silva, I. P.: Episodes of high productivity and cooling in the early Aptian Alpine Tethys, Geology, 27, 657-660, https://doi.org/10.1130/00917613(1999)027<0657:EOHPAC>2.3.CO;2, 1999.

Holland H. D.: The Chemistry of the Atmosphere and Oceans, Wiley, New York, USA, 1978.

Hu, X., Zhao, K., Yilmaz, I. O., and Li, Y.: Stratigraphic transition and palaeoenvironmental changes from the Aptian oceanic anoxic event 1a (OAE1a) to the oceanic red bed 1 (ORB1) in the Yenicesihlar section, central Turkey, Cretaceous Res., 38, 40-51, https://doi.org/10.1016/j.cretres.2012.01.007, 2012.

Ingall, E. and Jahnke, R.: Evidence for enhanced phosphorus regeneration from marine sediments overlain by oxygen depleted waters, Geochim. Cosmochim. Ac., 58, 2571-2575, https://doi.org/10.1016/0016-7037(94)90033-7, 1994.

Ingall, E. D.: Biogeochemistry: phosphorus burial, Nat. Geosci., 3, 521-522, https://doi.org/10.1038/ngeo926, 2010.

Jarvis, I., Lignum, J. S., Gröcke, D. R., Jenkyns, H. C., and Pearce, M. A.: Black shale deposition, atmospheric $\mathrm{CO}_{2}$ drawdown, and cooling during the Cenomanian-Turonian Oceanic Anoxic Event, Paleoceanography, 26, PA3201, https://doi.org/10.1029/2010PA002081, 2011.

Jarvis, I. A. N., Gale, A. S., Jenkyns, H. C., and Pearce, M. A.: Secular variation in Late Cretaceous carbon isotopes: a new $\delta^{13} \mathrm{C}$ carbonate reference curve for the
Cenomanian-Campanian (99.6-70.6 Ma), Geol. Mag., 143, 561608, https://doi.org/10.1017/S0016756806002421, 2006.

Jenkyns, H. C.: Cretaceous anoxic events: from continents to oceans, J. Geol. Soc. London, 137, 171-188, https://doi.org/10.1029/2010pa002081,2011, 1980.

Jenkyns, H. C.: Carbon-isotope stratigraphy and paleoceanographic significance of the Lower Cretaceous shallow-water carbonates of Resolution Guyot, Mid-Pacific Mountains, in: Proceedings of the Ocean Drilling Program, Scientific Results, 143, edited by: Winterer, E. L., Sager, W. W., Firth, J. V., and Sinton, J. M., Ocean Drilling Program, College Station, 99-108, https://doi.org/10.2973/odp.proc.sr.143.213.1995, 1995.

Jenkyns, H. C.: Evidence for rapid climate change in the MesozoicPalaeogene greenhouse world, Philos. T. Roy. Soc. A, 361, 18851916, https://doi.org/10.1098/rsta.2003.1240, 2003.

Jenkyns, H. C.: Geochemistry of oceanic anoxic events, Geochem. Geophy. Geosy., 11, Q03004, https://doi.org/10.1029/2009GC002788, 2010.

Jenkyns, H. C.: Transient cooling episodes during Cretaceous Oceanic Anoxic Events with special reference to OAE 1a (Early Aptian), Philos. T. Roy. Soc. A., 376, 20170073, https://doi.org/10.1098/rsta.2017.0073, 2018.

Jenkyns, H. C., Gale, A. S., and Corfield, R. M.: Carbon-and oxygen-isotope stratigraphy of the English Chalk and Italian Scaglia and its palaeoclimatic significance, Geol. Mag., 131, 134, https://doi.org/10.1017/S0016756800010451, 1994.

Jenkyns, H. C., Matthews, A., Tsikos, H., and Erel, Y.: Nitrate reduction, sulfate reduction, and sedimentary iron isotope evolution during the Cenomanian-Turonian oceanic anoxic event, Paleoceanography, 22, PA3208, https://doi.org/10.1029/2006PA001355, 2007.

Jenkyns, H. C., Dickson, A. J., Ruhl, M., and Van den Boorn, S. H.: Basalt-seawater interaction, the Plenus Cold Event, enhanced weathering and geochemical change: deconstructing Oceanic Anoxic Event 2 (Cenomanian-Turonian, Late Cretaceous), Sedimentology, 64, 16-43, https://doi.org/10.1111/sed.12305, 2017.

Katz, M. E., Wright, J. D., Miller, K. G., Cramer, B. S., Fennel, K., and Falkowski, P. G.: Biological overprint of the geological carbon cycle, Mar. Geol., 217, 323-338, https://doi.org/10.1016/j.margeo.2004.08.005, 2005.

Keller, C. E., Hochuli, P. A., Weissert, H., Bernasconi, S. M., Giorgioni, M., and Garcia, T. I.: A volcanically induced climate warming and floral change preceded the onset of OAE1a (Early Cretaceous), Palaeogeogr. Palaeocl., 305, 43-49, https://doi.org/10.1016/j.palaeo.2011.02.011, 2011.

Keller, G., Berner, Z., Adatte, T., and Stueben, D.: CenomanianTuronian and $\delta^{13} \mathrm{C}$, and $\delta^{18} \mathrm{O}$, sea level and salinity variations at Pueblo, Colorado, Palaeogeogr. Palaeocl., 211, 19-43, https://doi.org/10.1016/j.palaeo.2004.04.003, 2004.

Kochhann, K. G. D., Koutsoukos, A. M., and Fauth, G.: Aptian/Albian benthic foraminifera from DSDP Site 364 (offshore Angola): A paleoenvironmental and paleobiogeographic appraisal, Cretaceous Res., 48, 1-11, https://doi.org/10.1016/j.cretres.2013.11.009, 2014.

Kolonic, S., Wagner, T., Forster, A., Sinninghe Damsté, J. S., Walsworth-Bell, B., Erba, E., Turgeon, S., Brumsack, H.-J., Chellai, E. H., Tsikos, H., Kuhnt, W., and Kuypers, M. M. M.: Black shale deposition on the northwest African Shelf during the Cenomanian/Turonian oceanic anoxic event: Climate coupling 
and global organic carbon burial, Paleoceanography, 20, PA1006, https://doi.org/10.1029/2003PA000950, 2005.

Kuhnt, W., Thurow, J., Wiedmann, J., and Herbin, J. P.: Oceanic anoxic conditions around the Cenomanian/Turonian Boundary and the response of the biota, in: Biogeochemistry of Black Shales (Vol. 60), edited by: Degens, E. T., Meyers, P. A., and Brassell, S. C., Mitteilungen aus dem Geologischen Institut der Univ. Hamburg, Germany, 205-246, 1986.

Kuhnt, W., Herbin, J., Thurow, J., and Wiedemann, J.: Distribution of Cenomanian-Turonian organic facies in the western Mediterranean and along the adjacent Atlantic margin, in: Deposition of organic facies (Vol. 30), Amer. Assoc. Petroleum Geologists, 133-160, 1990.

Kuhnt, W., Nederbragt, A., and Leine, L.: Cyclicity of CenomanianTuronian organic-carbon-rich sediments in the Tarfaya Atlantic coastal basin (Morocco), Cretaceous Res., 18, 587-601, https://doi.org/10.1006/cres.1997.0076, 1997.

Kuhnt, W., Luderer, F., Nederbragt, S., Thurow, J., and Wagner, T.: Orbital-scale record of the late Cenomanian-Turonian oceanic anoxic event (OAE-2) in the Tarfaya Basin (Morocco), Int. J. Earth Sci., 94, 147-159, https://doi.org/10.1007/s00531-0040440-5, 2005.

Kuhnt, W., Holbourn, A., and Moullade, M.: Transient global cooling at the onset of early Aptian oceanic anoxic event (OAE) 1a, Geology, 39, 323-326, https://doi.org/10.1130/G31554.1, 2011.

Kuhnt, W., Holbourn, A. E., Beil, S., Aquit, M., Krawczyk, T., Flögel, S., Chellai, E. H., and Jabour, H.: Unraveling the onset of Cretaceous Oceanic Anoxic Event 2 in an extended sediment archive from the TarfayaLaayoune Basin, Morocco, Paleoceanography, 32, 923-946, https://doi.org/10.1002/2017PA003146, 2017.

Kump, L. R.: Interpreting carbon-isotope excursions: Strangelove oceans, Geology, 19, 299-302, https://doi.org/10.1130/00917613(1991)019<0299:ICIESO>2.3.CO;2, 1991.

Kump, L. R. and Arthur, M. A.: Interpreting carbon-isotope excursions: carbonate and organic matter, Chem. Geol., 161, 181-198, https://doi.org/10.1016/S0009-2541(99)00086-8, 1999.

Kuypers, M. M., Pancost, R. D., and Damste, J. S. S.: A large and abrupt fall in atmospheric $\mathrm{CO}_{2}$ concentration during Cretaceous times, Nature, 399, 342-345, https://doi.org/10.1038/20659, 1999.

Kuypers, M. M., van Breugel, Y., Schouten, S., Erba, E., and Siminghe Damsté, J. S.: $\mathrm{N}_{2}$-fixing cyanobacteria supplied nutrient $\mathrm{N}$ for Cretaceous oceanic anoxic events, Geology, 32, 853-856, https://doi.org/10.1130/G20458.1, 2004.

Larson, R. L.: Latest pulse of Earth: Evidence for a mid-Cretaceous superplume, Geology, 19, 547-550, https://doi.org/10.1130/00917613(1991)019<0547:LPOEEF>2.3.CO;2, 1991.

Larson, R. L. and Erba, E.: Onset of the Mid-Cretaceous greenhouse in the Barremian-Aptian: Igneous events and the biological, sedimentary, and geochemical responses, Paleoceanography, 14, 663-678, https://doi.org/10.1029/1999PA900040, 1999.

Laskar, J., Robutel, P., Joutel, F., Gastineau, M., Correia, A. C. M., and Levrard, B.: A long-term numerical solution for the insolation quantities of the Earth, Astron. Astrophys., 428, 261-285, https://doi.org/10.1051/0004-6361:20041335, 2004.

Laskar, J., Fienga, A., Gastineau, M., and Manche, H.: La2010: a new orbital solution for the long-term motion of the Earth,
Astron. Astrophys., 532, A89, https://doi.org/10.1051/00046361/201116836, 2011a.

Laskar, J., Gastineau, M., Delisle, J. B., Farrés, A., and Fienga, A.: Strong chaos induced by close encounters with Ceres and Vesta, Astron. Astrophys., 532, 53, https://doi.org/10.1051/00046361/201117504, 2011b.

Leine, L.: Geology of the Tarfaya oil shale deposit, Morocco, Geol. Mijnbouw, 65, 57-74, 1986.

Li, Y. X., Bralower, T. J., Montañez, I. P., Osleger, D. A., Arthur, M. A., Bice, D. M., Herbert, T. D., Erba, E., and Silva, I. P. Toward an orbital chronology for the early Aptian oceanic anoxic event (OAE1a, 120 Ma), Earth Planet. Sc. Lett., 271, 88-100, https://doi.org/10.1016/j.epsl.2008.03.055, 2008.

Li, R., Xu, J., Li, X., Shi, Z., and Harrison, P. J.: Spatiotemporal variability in phosphorus species in the Pearl River Estuary: Influence of the river discharge, Sci. Rep., 7, 13649, https://doi.org/10.1038/s41598-017-13924-w, 2017a.

Li, Y. X., Montanez, I. P., Liu, Z., and Ma, L.: Astronomical constraints on global carbon-cycle perturbation during Oceanic Anoxic Event 2 (OAE2), Earth Planet. Sc. Lett., 462, 35-46, https://doi.org/10.1016/j.epsl.2017.01.007, 2017b.

Lorenzen, J., Kuhnt, W., Holbourn, A., Flögel, S., Moullade, M., and Tronchetti, G.: A new sediment core from the Bedoulian (Lower Aptian) stratotype at RoquefortLa Bédoule, SE France, Cretaceous Res., 39, 6-16, https://doi.org/10.1016/j.cretres.2012.03.019, 2013.

Ma, C., Meyers, S. R., Sageman, B. B., Singer, B. S., and Jicha, B. R.: Testing the astronomical time scale for oceanic anoxic event 2 , and its extension into Cenomanian strata of the Western Interior Basin (USA), Geol. Soc. Am. Bull., 126, 974-989, https://doi.org/10.1130/B30922.1, 2014.

Mackenzie, F. T., Ver, L. M., and Lerman, A.: Centuryscale nitrogen and phosphorus controls of the carbon cycle, Chem. Geol., 190, 13-32, https://doi.org/10.1016/S00092541(02)00108-0, 2002.

Malinverno, A., Erba, E., and Herbert, T. D.: Orbital tuning as an inverse problem: Chronology of the early Aptian oceanic anoxic event 1a (Selli Level) in the Cismon APTICORE, Paleoceanography, 25, PA2203, https://doi.org/10.1029/2009PA001769, 2010.

Mann, M. E. and Lees, J. M.: Robust estimation of background noise and signal detection in climatic time series, Climatic change, 33, 409-445, https://doi.org/10.1007/BF00142586, 1996.

März, C., Poulton, S. W., Beckmann, B., Küster, K., Wagner, T., and Kasten, S.: Redox sensitivity of $\mathrm{P}$ cycling during marine black shale formation: dynamics of sulfidic and anoxic, nonsulfidic bottom waters, Geochim. Cosmochim. Ac., 72, 37033717, https://doi.org/10.1016/j.gca.2008.04.025, 2008.

Masse, J. P., Bouaziz, S., Amon, E. O., Baraboshin, E., Tarkowski, R. A., Bergerat, F., Sandulescu, M., Platel, J. P., Canerot, J., and Guiraud, R.: Early Aptian (112-114 Ma), in: Atlas Peri-Tethys, Palaeogeographical Maps, edited by: Dercourt, J., Gaetani, M., and Vrielynck, B., CCGM, Paris, 119-127, 2000.

Masure, E., Raynaud, J. F., Pons, D., and de Reneville, P.: Palynologie du stratotype historique de l'Aptien inférieur dans la région de Cassis-La Bédoule (SE France), Géologie méditerranéenne, 25, 263-287, 1998.

Menegatti, A. P., Weissert, H., Brown, R. S., Tyson, R. V., Farrimond, P., Strasser, A., and Caron, M.: High- 
resolution $\delta^{13} \mathrm{C}$ stratigraphy through the early Aptian "Livello Selli" of the Alpine Tethys, Paleoceanography, 13, 530-545, https://doi.org/10.1029/98PA01793, 1998.

Meyers, S. R.: Astrochron: An R package for astrochronology, available at: https://cran.r-project.org/package=astrochron (last access: 1 September 2019), 2014.

Meyers, S. R. and Sageman, B. B.: Quantification of deep-time orbital forcing by average spectral misfit, Am. J. Sci., 307, 773792, https://doi.org/10.2475/05.2007.01, 2007

Meyers, S. R., Sageman, B. B., and Arthur, M. A.: Obliquity forcing of organic matter accumulation during Oceanic Anoxic Event 2, Paleoceanography, 27, PA3212, https://doi.org/10.1029/2012PA002286, 2012a.

Meyers, S. R., Siewert, S. E., Singer, B. S., Sageman, B. B., Condon, D. J., Obradovich, J. D., Jicha, B. R., and Sawyer, D. A.: Intercalibration of radioisotopic and astrochronologic time scales for the Cenomanian-Turonian boundary interval, Western Interior Basin, USA, Geology, 40, 7-10, https://doi.org/10.1130/G32261.1, 2012b.

Mort, H. P., Adatte, T., Follmi, K. B., Keller, G., Steinmann, P., Matera, V., Berner, Z., and Stuben, D.: Phosphorus and the roles of productivity and nutrient recycling during oceanic anoxic event 2, Geology, 35, 483-486, https://doi.org/10.1130/G23475A.1, 2007.

Mort, H. P., Adatte, T., Keller, G., Bartels, D., Föllmi, K. B., Steinmann, P., Berner, Z., and Chellai, E. H.: Organic carbon deposition and phosphorus accumulation during Oceanic Anoxic Event 2 in Tarfaya, Morocco, Cretaceous Res., 29, 1008-1023, https://doi.org/10.1016/j.cretres.2008.05.026, 2008.

Moullade, M., Tronchetti, G., Granier, B., Bornemann, A., Kuhnt, W., and Lorenzen, J.: High-resolution integrated stratigraphy of the OAE1a and enclosing strata from core drillings in the Bedoulian stratotype (Roquefort-La Bédoule, SE France), Cretaceous Res., 56, 119-140, https://doi.org/10.1016/j.cretres.2015.03.004, 2015

Mulitza, S., Prange, M., Stuut, J. B., Zabel, M., von Dobeneck, T., Itambi, A. C., Nizou, J., Schulz, M., and Wefer, G.: Sahel megadroughts triggered by glacial slowdowns of Atlantic meridional overturning, Paleoceanography, 23, PA4206, https://doi.org/10.1029/2008PA001637, 2008.

Naafs, B. D. A. and Pancost, R. D.: Sea-surface temperature evolution across Aptian oceanic anoxic event 1a, Geology, 44, 959962, https://doi.org/10.1130/G38575.1, 2016.

Naafs, B. D. A., Castro, J. M., DeGea, G. A., Quijano, M. L., Schmidt, D. N., and Pancost, R. D.: Gradual and sustained carbon dioxide release during Aptian oceanic anoxic event 1a, Nat. Geosci., 9, 135-139, https://doi.org/10.1038/ngeo2627, 2016.

Nederbragt, A. J. and Fiorentino, A.: Stratigraphy and palaeoceanography of the Cenomanian-Turonian boundary event in Oued Mellegue, north-western Tunisia, Cretaceous Res., 20, $47-$ 62, https://doi.org/10.1006/cres.1998.0136, 1999.

Nederbragt, A. J., Thurow, J., Vonhof, H., and Brumsack, H. J.: Modelling oceanic carbon and phosphorus fluxes: implications for the cause of the late Cenomanian Oceanic Anoxic Event (OAE2), J. Geol. Soc. London, 161, 721-728, https://doi.org/10.1144/0016-764903-075, 2004.

Nemoto, T. and Hasegawa, T.: Submillennial resolution carbon isotope stratigraphy across the Oceanic Anoxic Event 2 horizon in the Tappu section, Hokkaido, Japan, Palaeogeogr. Palaeocl., 309, 271-280, https://doi.org/10.1016/j.palaeo.2011.06.009, 2011.

Niebuhr, B.: Geochemistry and time-series analyses of orbitally forced Upper Cretaceous marl-limestone rhythmites (Lehrte West Syncline, northern Germany), Geol. Mag., 142, 31-55, https://doi.org/10.1017/S0016756804009999, 2005.

Noffke, A., Hensen, C., Sommer, S., Scholz, F., Bohlen, L., Mosch, T., Graco, M., and Wallmann, K.: Benthic iron and phosphorus fluxes across the Peruvian oxygen minimum zone, Limnol. Oceanogr., 57, 851-867, https://doi.org/10.4319/lo.2012.57.3.0851, 2012.

O’Brien, C. L., Robinson, S. A., Pancost, R. D., Damste, J. S. S., Schouten, S., Lunt, D. J., Alsenz, H., Bornemann, A., Bottini, C., Brassell, S. C., Farnsworth, A., Forster, A., Huber, B. T., Inglis, G. N., Jenkyns, H. C., Linnert, C., Littler, K., Markwick, P., McAnena, A., Mutterlose, J., Naafs, D. A., Püttmann, W., Sluijs, A., van Helmond, N. A. G. M., Vellekoop, J., Wagner, T., and Wrobel, N. E.: Cretaceous sea-surface temperature evolution: Constraints from TEX86 and planktonic foraminiferal oxygen isotopes, Earth-Sci. Rev., 172, 224-247, https://doi.org/10.1016/j.earscirev.2017.07.012, 2017.

Oxmann, J. F., Pham, Q. H., and Lara, R. J.: Quantification of individual phosphorus species in sediment: a sequential conversion and extraction method, Eur. J. Soil Sci., 59, 1177-1190, https://doi.org/10.1111/j.1365-2389.2008.01062.x, 2008.

Pälike, H., Norris, R. D., Herrle, J. O., Wilson, P. A., Coxall, H. K., Lear, C. H., Shackleton, N. J., Tripati, A. K., and Wade, B. S.: The heartbeat of the Oligocene climate system, Science, 314, 1894-1898, https://doi.org/10.1126/science.1133822, 2006.

Patterson, M. O., McKay, R., Naish, T., Escutia, C., JimenezEspejo, F. J., Raymo, M. E., Meyers, S. R., Tauxe, L., Brinkhuis, H., and IODP Expedition 318 Scientists: Orbital forcing of the East Antarctic ice sheet during the Pliocene and Early Pleistocene, Nat. Geosci., 7, 841-847, https://doi.org/10.1038/ngeo2273, 2014.

Paul, C. R. C., Lamolda, M. A., Mitchell, S. F., Vaziri, M. R., Gorostidi, A., and Marshall, J. D.: The CenomanianTuronian boundary at Eastbourne (Sussex, UK): a proposed European reference section, Palaeogeogr. Palaeocl., 150, 83-121, https://doi.org/10.1016/S0031-0182(99)00009-7, 1999.

Peterson, L. C., Haug, G. H., Hughen, K. A., and Röhl, U.: Rapid changes in the hydrologic cycle of the tropical Atlantic during the last glacial, Science, 290, 1947-1951, https://doi.org/10.1126/science.290.5498.1947, 2000.

Petrizzo, M. R., Huber, B. T., Wilson, P. A., and MacLeod, K. G.: Late Albian paleoceanography of the western subtropical North Atlantic, Paleoceanography, 23, PA1213, https://doi.org/10.1029/2007PA001517, 2008.

Poulton, S. W. and Canfield, D. E.: Ferruginous conditions: a dominant feature of the ocean through Earth's history, Elements, 7, 107-112, https://doi.org/10.2113/gselements.7.2.107, 2011.

Poulton, S. W., Henkel, S., März, C., Urquhart, H., Flögel, S., Kasten, S., Siminghe Damste, J. S., and Wagner, T.: A continentalweathering control on orbitally driven redox-nutrient cycling during Cretaceous Oceanic Anoxic Event 2, Geology, 43, $963-$ 966, https://doi.org/10.1130/G36837.1, 2015.

R Core Team: R: A language and environment for statistical computing, R Foundation for Statistical Computing, Vienna, Austria, 
available at: https://www.R-project.org/ (last access: 1 September 2019), 2018.

Rau, G. H., Arthur, M. A., and Dean, W. E.: ${ }^{15} \mathrm{~N} /{ }^{14} \mathrm{~N}$ variations in Cretaceous Atlantic sedimentary sequences: Implication for past changes in marine nitrogen biogeochemistry, Earth Planet. Sc. Lett., 82, 269-279, https://doi.org/10.1016/0012821X(87)90201-9, 1987

Reboulet, S., Giraud, F., Colombié, C., and Carpentier, A.: Integrated stratigraphy of the Lower and Middle Cenomanian in a Tethyan section (Blieux, southeast France) and correlations with Boreal basins, Cretaceous Res., 40, 170-189, https://doi.org/10.1016/j.cretres.2012.06.006, 2013.

Redfield, A. C.: The biological control of chemical factors in the environment, Am. Sci., 46, 230A-221, 1958.

Redfield, A. C.: The influence of organisms on the composition of seawater, in: The sea, edited by: Hill, M. N., Interscience, New York, USA, 2, 26-77, 1963.

Rigby, D. and Batts, B. D.: The isotopic composition of nitrogen in Australian coals and oil shales, Chem. Geol., 58, 273-282, https://doi.org/10.1016/0168-9622(86)90016-3, 1986.

Riggs, S. R.: Phosphorite sedimentation in Florida - a model phosphogenic system, Econ. Geol., 74, 285-314, https://doi.org/10.2113/gsecongeo.74.2.285, 1979.

Roth, R., Ritz, S. P., and Joos, F.: Burial-nutrient feedbacks amplify the sensitivity of atmospheric carbon dioxide to changes in organic matter remineralisation, Earth Syst. Dynam., 5, 321-343, https://doi.org/10.5194/esd-5-321-2014, 2014.

Ruiz-Ortiz, P. A., Castro, J. M., de Gea, G. A., Jarvis, I., Molina, J. M., Nieto, L. M., Pancost, R. D., Quijano, M. L., Reolid, M., Skelton, P. W., and Weissert, H. J.: New drilling of the early Aptian OAE1a: the Cau core (Prebetic Zone, south-eastern Spain), Sci. Dril., 21, 41-46, https://doi.org/10.5194/sd-21-412016, 2016.

Ruttenberg, K. C.: The Global Phosphorus Cycle, in: Treatise on Geochemistry (Vol. 8), edited by: Turekian, K. K. and Holland, H. D., Elsevier, 585-643, https://doi.org/10.1016/B0-08-0437516/08153-6, 2003.

Ruttenberg, K. C. and Berner, R. A.: Authigenic apatite formation and burial in sediments from non-upwelling continental margins, Geochim. Cosmochim Ac., 57, 991-1007, https://doi.org/10.1016/0016-7037(93)90035-U, 1993.

Sageman, B. B., Meyers, S. R., and Arthur, M. A.: Orbital time scale and new $\mathrm{C}$-isotope record for CenomanianTuronian boundary stratotype, Geology, 34, 125-128, https://doi.org/10.1130/G22074.1, 2006.

Schlanger, S. O. and Jenkyns, H. C.: Cretaceous oceanic anoxic events: causes and consequences, Geol. Mijnbouw, 55, 179-184, 1976.

Schlanger, S. O., Jenkyns, H. C., and Premoli-Silva, I.: Volcanism and vertical tectonics in the Pacific Basin related to global Cretaceous transgressions, Earth Planet. Sc. Lett., 52, 435-449, https://doi.org/10.1016/0012-821X(81)90196-5, 1981.

Schlanger, S. O., Arthur, M. A., Jenkyns, H. C., and Scholle, P. A.: The Cenomanian-Turonian Oceanic Anoxic Event, I. Stratigraphy and distribution of organic carbon-rich beds and the marine $\delta^{13}$ C excursion, Geol. Soc. (London) Spec Publ, 26, 371-399, https://doi.org/10.1144/GSL.SP.1987.026.01.24, 1987.

Scholle, P. A. and Arthur, M. A.: Carbon isotope fluctuations in Cretaceous pelagic limestones: potential strati- graphic and petroleum exploration tool, AAPG Bull., 64, 67-87, https://doi.org/10.1306/2F91892D-16CE-11D78645000102C1865D, 1980.

Scholz, F., Beil, S., Flögel, S., Lehmann, M. F., Holbourn, A., Wallmann, K., and Kuhnt, W.: Oxygen minimum zone-type biogeochemical cycling in the Cenomanian-Turonian Proto-North Atlantic across Oceanic Anoxic Event 2, Earth Planet. Sc. Lett., 517, 50-60, https://doi.org/10.1016/j.epsl.2019.04.008, 2019.

Schroller-Lomnitz, U., Hensen, C., Dale, A. W., Scholz, F., Clemens, D., Sommer, S., Noffke, A., and Wallmann, K.: Dissolved benthic phosphate, iron and carbon fluxes in the Mauritanian upwelling system and implications for ongoing deoxygenation, Deep-Sea Res. Pt. I, 143, 70-84, https://doi.org/10.1016/j.dsr.2018.11.008, 2019.

Schulz, H. N. and Schulz, H. D.: Large sulfur bacteria and the formation of phosphorite, Science, 307, 416-418, https://doi.org/10.1126/science.1103096, 2005.

Scott, R. W.: A Cretaceous chronostratigraphic database: construction and applications, Carnets Geol., 14, 15-37, https://doi.org/10.4267/2042/53522, 2014

Scott, R. W.: Barremian-Aptian-Albian carbon isotope segments as chronostratigraphic signals: numerical age calibration and durations, Stratigraphy, 13, 21-47, 2016.

Sinninghe Damsté, J. S., van Bentum, E. C., Reichart, G. J., Pross, J., and Schouten, S.: $\mathrm{A} \mathrm{CO}_{2}$ decrease-driven cooling and increased latitudinal temperature gradient during the midCretaceous Oceanic Anoxic Event 2, Earth Planet. Sc. Lett., 293, 97-103, https://doi.org/10.1016/j.epsl.2010.02.027, 2010.

Slomp, C. P. and Van Cappellen, P.: The global marine phosphorus cycle: sensitivity to oceanic circulation, Biogeosciences, 4, 155171, https://doi.org/10.5194/bg-4-155-2007, 2007.

Slomp, C. P., Thomson, J., and de Lange, G. J.: Controls on phosphorus regeneration and burial during formation of eastern Mediterranean sapropels, Mar. Geol., 203, 141-159, https://doi.org/10.1016/S0025-3227(03)00335-9, 2004.

Smith, S. V.: Phosphorus versus nitrogen limitation in the marine environment, Limnol. Oceanogr., 29, 1149-1160, https://doi.org/10.4319/lo.1984.29.6.1149, 1984.

Stein, M., Föllmi, K. B., Westermann, S., Godet, A., Adatte, T., Matera, V., Fleitmann, D., and Berner, Z.: Progressive palaeoenvironmental change during the late Barremianearly Aptian as prelude to Oceanic Anoxic Event 1a: Evidence from the Gorgo a Cerbara section (Umbria-Marche basin, central Italy), Palaeogeogr. Palaeocl., 302, 396-406, https://doi.org/10.1016/j.palaeo.2011.01.025, 2011.

Tisserand, A., Malaizé, B., Jullien, E., Zaragosi, S., Charlier, K., and Grousset, F.: African monsoon enhancement during the penultimate glacial period (MIS $6.5 \sim 170 \mathrm{ka}$ ) and its atmospheric impact, Paleoceanography, 24, PA2220, https://doi.org/10.1029/2008PA001630, 2009.

Trabucho-Alexandre, J., Tuenter, E., Henstra, G. A., van der Zwan, K. J., van de Wal, R. S., Dijkstra, H. A., and de Boer, P. L.: The mid-Cretaceous North Atlantic nutrient trap: black shales and OAEs, Paleoceanography, 25, PA4201, https://doi.org/10.1029/2010PA001925, 2010.

Tsikos, H., Jenkyns, H. C., Walsworth-Bell, B., Petrizzo, M. R., Forster, A., Kolonic, S., Erba, E., Premoli Silva, I., Baas, M., Wagner, T., and Sinninghe Damsté, J. S.: Carbonisotope stratigraphy recorded by the Cenomanian-Turonian 
Oceanic Anoxic Event: correlation and implications based on three key localities, J. Geol. Soc. London, 161, 711-719, https://doi.org/10.1144/0016-764903-077, 2004.

Turgeon, S. C. and Creaser, R. A.: Cretaceous oceanic anoxic event 2 triggered by a massive magmatic episode, Nature, 454, 323 326, https://doi.org/10.1038/nature07076, 2008.

Tyrrell, T.: The relative influences of nitrogen and phosphorus on oceanic primary production, Nature, 400, 525-531, https://doi.org/10.1038/22941, 1999.

van Bentum, E. C., Reichart, G.-J., Forster, A., and Sinninghe Damsté, J. S.: Latitudinal differences in the amplitude of the OAE-2 carbon isotopic excursion: $p \mathrm{CO}_{2}$ and paleo productivity, Biogeosciences, 9, 717-731, https://doi.org/10.5194/bg-9-7172012, 2012.

Voigt, S., Wilmsen, M., Mortimore, R. N., and Voigt, T.: Cenomanian palaeotemperatures derived from the oxygen isotopic composition of brachiopods and belemnites: evaluation of Cretaceous palaeotemperature proxies, Int. J. Earth Sci., 92, 285-299, https://doi.org/10.1007/s00531-003-0315-1, 2003.

Voigt, S., Gale, A. S., and Flögel, S.: Midlatitude shelf seas in the Cenomanian-Turonian greenhouse world: Temperature evolution and North Atlantic circulation, Paleoceanography, 19, PA4020, https://doi.org/10.1029/2004PA001015, 2004.

Voigt, S., Aurag, A., Leis, F., and Kaplan, U.: Late Cenomanian to Middle Turonian high-resolution carbon isotope stratigraphy: New data from the Münsterland Cretaceous Basin, Germany, Earth Planet. Sc. Lett., 253, 196-210, https://doi.org/10.1016/j.epsl.2006.10.026, 2007.

Voigt, S., Erbacher, J., Mutterlose, J., Weiss, W., Westerhold, T., Wiese, F., Wilmsen, M., and Wonik, T.: The CenomanianTuronian of the Wunstorf section-(North Germany): global stratigraphic reference section and new orbital time scale for Oceanic Anoxic Event 2, Newsl. Stratigr., 43, 65-89, https://doi.org/10.1127/0078-0421/2008/0043-0065, 2008.

Wagner, T., Wallmann, K., Herrle, J. O., Hofmann, P., and Stuesser, I.: Consequences of moderate $\sim 25000 \mathrm{yr}$ lasting emission of light $\mathrm{CO}_{2}$ into the mid-Cretaceous ocean, Earth Planet. Sc. Lett., 259, 200-211, https://doi.org/10.1016/j.eps1.2007.04.045, 2007.

Wallmann, K.: Feedbacks between oceanic redox states and marine productivity: A model perspective focused on benthic phosphorus cycling, Global Biogeochem. Cy., 17, 1084, https://doi.org/10.1029/2002GB001968, 2003.
Wallmann, K.: Phosphorus imbalance in the global ocean?, Global Biogeochem. Cy., 24, GB4030, https://doi.org/10.1029/2009GB003643, 2010.

Wallmann, K., Flögel, S., Scholz, F., Dale, A. W., Kemena, T. P., Steinig, S., and Kuhnt, W.: Periodic changes in the Cretaceous ocean and climate caused by marine redox see-saw, Nat. Geosci., 12, 456-461, https://doi.org/10.1038/s41561-019-0359-x, 2019.

Weaver, C. E.: Potassium, illite and the ocean, Geochim. Cosmochim. Ac., 31, 2181-2196, https://doi.org/10.1016/00167037(67)90060-9, 1967.

Weaver, C. E.: Developments in Sedimentology 44 - Clays, muds, and shales, Elsevier, 1989.

Weissert, H., Lini, A., Föllmi, K. B., and Kuhn, O.: Correlation of Early Cretaceous carbon isotope stratigraphy and platform drowning events: a possible link?, Palaeogeogr. Palaeocl., 137, 189-203, https://doi.org/10.1016/S0031-0182(97)00109-0, 1998.

Weltje, G. J. and Tjallingii, R.: Calibration of XRF core scanners for quantitative geochemical logging of sediment cores: theory and application, Earth Planet. Sc. Lett., 274, 423-438, https://doi.org/10.1016/j.epsl.2008.07.054, 2008.

Wendler, I.: A critical evaluation of carbon isotope stratigraphy and biostratigraphic implications for Late Cretaceous global correlation, Earth-Sci. Rev., 126, 116-146, https://doi.org/10.1016/j.earscirev.2013.08.003, 2013.

Wilson, J.: Did the Atlantic close and then reopen?, Nature, 211, 676-681, https://doi.org/10.1038/211676a0, 1966.

Worsley, T. R., Nance, R. D., and Moody, J. B.: Tectonic cycles and the history of the Earth's biogeochemical and paleoceanographic record, Paleoceanography, 1, 233-263, https://doi.org/10.1029/PA001i003p00233, 1986.

Yao, H., Chen, X., Melinte-Dobrinescu, M. C., Wu, H., Liang, H., and Weissert, H.: Biostratigraphy, carbon isotopes and cyclostratigraphy of the AlbianCenomanian transition and Oceanic Anoxic Event 1d in southern Tibet, Palaeogeogr. Palaeocl., 499, 45-55, https://doi.org/10.1016/j.palaeo.2018.03.005, 2018. 